Landslides (2017) 14:2009-2023

DOI 10.1007/s10346-017-0840-9

Received: 18 January 2017

Accepted: 5 May 2017

Published online: 20 June 2017

(c) The Author(s) 2017

This article is an open access publication
Thomas Zieher - Barbara Schneider-Muntau · Martin Mergili

\section{Are real-world shallow landslides reproducible by physically-based models? Four test cases in the Laternser valley, Vorarlberg (Austria)}

\begin{abstract}
In contrast to the complex nature of slope failures, physically-based slope stability models rely on simplified representations of landslide geometry. Depending on the modelling approach, landslide geometry is reduced to a slope-parallel layer of infinite length and width (e.g., the infinite slope stability model), a concatenation of rigid bodies (e.g. Janbu's model), or a $3 \mathrm{D}$ representation of the slope failure (e.g., Hovland's model). In this paper, the applicability of four slope stability models is tested at four shallow landslide sites where information on soil material and landslide geometry is available. Soil samples were collected in the field for conducting respective laboratory tests. Landslide geometry was extracted from pre- and post-event digital terrain models derived from airborne laser scanning. Results for fully saturated conditions suggest that a more complex representation of landslide geometry leads to increasingly stable conditions as predicted by the respective models. Using the maximum landslide depth and the median slope angle of the sliding surfaces, the infinite slope stability model correctly predicts slope failures for all test sites. Applying a $2 \mathrm{D}$ model for the slope failures, only two test sites are predicted to fail while the two other remain stable. Based on $3 \mathrm{D}$ models, none of the slope failures are predicted correctly. The differing results may be explained by the stabilizing effects of cohesion in shallower parts of the landslides. These parts are better represented in models which include a more detailed landslide geometry. Hence, comparing the results of the applied models, the infinite slope stability model generally yields a lower factor of safety due to the overestimation of landslide depth and volume. This simple approach is considered feasible for computing a regional overview of slope stability. For the local scale, more detailed studies including comprehensive material sampling and testing as well as regolith depth measurements are necessary.
\end{abstract}

Keywords Slope failure $\cdot$ Landslide geometry Infinite slope stability model $\cdot$ Janbu's model $\cdot$ r.slope.stability $\cdot$ Differential digital terrain model

\section{Introduction}

Landslides are a common geomorphological feature in mountain regions often putting lives and infrastructure at risk. The term "shallow landslides" typically refers to translational sliding movements of soil material (earth and/or debris), characterized by a pre-defined, planar sliding surface in a depth of up to $2.0 \mathrm{~m}$ (e.g., Cruden and Varnes 1996; Hungr et al. 2014). In the past decades, the Laternser valley (Vorarlberg, Austria) was repeatedly affected by rainfall-triggered shallow landslides (Andrecs et al. 2002; Markart et al. 2007). Since the 1950s, more than 800 shallow landslides have been documented in a comprehensive shallow landslide inventory (Zieher et al. 2016). To be aware of the associated risks, it is necessary to assess shallow landslide susceptibility, hazard, and risk areawide. Various techniques have been proposed for landslide susceptibility modelling/mapping (i.e., heuristic, statistically-, and physically-based). Amongst them, physically-based landslide susceptibility models employ physical laws to assess slope stability. They typically rely on the limit equilibrium concept relating stabilizing to destabilizing forces. The proposed techniques differ in the complexity of the considered landslide geometry (shape of the potential sliding surface) in two (e.g., Bishop 1955; Fellenius 1927; Janbu 1954; Morgenstern and Price 1965) and three dimensions (e.g., Hovland 1977; Hungr 1987; Lam and Fredlund 1993; Mergili et al. 2014). While slope failures show complex geometrical shapes in nature, their representation in physically-based slope stability models is simplified. Shallow landslides are approximated by either a slope-parallel layer of infinite length and width (e.g., the infinite slope stability model, ISSM), a concatenation of rigid bodies of infinite width (e.g., Janbu's model), or a representation of discrete, $3 \mathrm{D}$ units (columns on the basis of raster cells; e.g., the r.slope.stability model, RSS). Consequently, the considered sliding surfaces are either planar (ISSM), an irregular $2 \mathrm{D}$ polyline $(2 \mathrm{D}$ models) or an irregular $3 \mathrm{D}$ surface (3D models). Furthermore, some of these approaches include inter-slice forces between the geometrical subunits (e.g., Janbu 1954) while others assume them to cancel each other out (e.g., Fellenius 1927). The result of physically-based slope stability models based on the limit equilibrium concept is a dimensionless factor of safety (FOS) which is a quantitative measure of slope stability. Slope failures are predicted, if the FOS falls below 1 . In engineering, these models are usually applied at local scale to evaluate the stability of a single slope unit in the context of a specific engineering task. For the assessment of slope stability at catchment scale, the ISSM has proven feasible in combination with geographical information systems (GIS). Most spatially distributed physically-based shallow landslide susceptibility models include the infinite slope approach, often combined with an infiltration model (e.g., Baum et al. 2008; Dietrich et al. 1995). Recently, models including a more complex landslide geometry (e.g., ellipsoidal and truncated sliding surfaces) have been implemented in GIS (Mergili et al. 2014; Xie et al. 2006). For all these physically-based slope stability models, the result is a FOS map which is a spatially distributed quantitative measure of slope stability.

Besides geotechnical input parameters characterizing the involved material, physically-based models require data on topography (e.g., slope angle) and depth of the pre-defined sliding surface. Topographic data are usually derived from digital terrain models (DTMs), which have become readily available. The depth of the pre-defined sliding surface is more difficult to obtain. It can be assessed by (i) direct measurements (Andrecs et al. 2002; Wiegand et al. 2013), (ii) means of geophysics (Davis and Annan 1989; Sass 2007), or modelling (Dietrich et al. 1995; Catani et al. 2010). Moreover, depth and volume of past landslides can be 
assessed efficiently with the help of multi-temporal remotely sensed elevation data (Zieher et al. 2016).

Numerous studies have focussed on the area-wide assessment of slope stability at catchment scale by applying physically-based slope stability models which include the infinite slope approach (e.g., Baum et al. 2005; Gioia et al. 2016; Montrasio et al. 2011). In such studies, little attention has been paid to the effect of the simplified landslide geometry considered by the ISSM. However, this issue must be regarded for the interpretation of the resulting FOS maps. In this paper, four slope stability models including different representations of landslide geometry are tested at four sites affected by shallow landslides, where information on soil material properties and geometries of slope failures are available. Simplifications of the models with regard to landslide geometry are tested against realworld geometries of the selected cases. The applicability of the widely used infinite slope stability model is investigated in detail. The ISSM's predictions are compared to the results of models with $2 \mathrm{D}$ (Janbu's model) and 3D (r.slope.stability, 3DVA) approximations of the slope failures. For the comparison of the methods, models with comparable physical basis but different geometrical representations of the slope failures were chosen. Further influencing factors such as effects of high vegetation (root cohesion) or variable soil saturation were neglected. Omitting the root cohesion together with the assumption of completely saturated conditions is considered as worstcase scenarios. Under equal conditions for the applied models, the results are better comparable.

The objectives are as follows:

1. To conclude on the ability of the tested models to reproduce the observed landslides with the given parameterization;

2. To learn about the effects of different representations of landslide geometry on the respective model results;

3. On this basis, to identify potential pitfalls in slope stability modelling.

The present article is divided into four main sections. First, the study area including the landslide-triggering rainfall event in August 2005 is described in the "Study area" section. The conducted laboratory experiments, the landslide geometry data, and the modelling approaches are introduced in the "Materials and methods" section. Model results and comparisons are presented and discussed in the "Results and discussion" section. Finally, concluding remarks summarizing the key findings are provided in the "Conclusions" section.

Study area

The four test sites are located in the Laternser valley in Vorarlberg, Austria (Fig. 1). This valley, extending about $13 \mathrm{~km}$ in the East-West direction, follows the general strike angle of the Bregenzerwald Mountains. The four sampled landslide locations are situated on the south-facing hillside in the vicinity of the valley's main settlements (Fig. 1). Abbreviations are given according to the closest settlements (BIN Bingadels, BON Bonacker, MAZ Mazona, ROH Rohnen). All four shallow landslides were triggered in the course of a rainfall event on 22/23 August 2005. The landslides at the locations BIN, BON, and ROH were also mapped by (Markart et al. 2007) immediately after the event. Table 1 shows the metadata for the four landslide sites.

\section{Tectonics and geology}

The tectonic structure of the valley is dominated by various nappes. Helvetic nappes in the western and northern part of the valley are characterized by competent limestones (e.g., Schrattenkalk, Seewerkalk) and marls with calcareous layers (e.g., Drusbergschichten). Superimposed to the south-east, ultrahelvetic nappes are mostly built up of clayey marls and shales (e.g., Leimernmergel). On top extending to the south-east, penninic nappes underlie more than half of the valley. These are characterized by sandstones (e.g., Reiselsberger Sandstein, Planknerbrückenserie) and thinly layered marls (e.g., Piesenkopfschichten) (Friebe 2007; Heissel et al. 1967; Oberhauser 1982; Oberhauser 1998). Above all, the widespread moraine deposits as well as hillside debris are overly susceptible to shallow landsliding. In many cases, subglacial till is reported to form an impermeable layer acting as a sliding surface for the unconsolidated material on top. Only in rare cases also subglacial till was mobilized. Additionally, marls of the Ultrahelveticum, often forming dip slopes, and less competent sandstones of the Penninicum are overly affected by shallow landslides (Zieher et al. 2016).

\section{Climate}

Due to the influence of oceanic air masses, the climate of Vorarlberg is generally more balanced compared to the whole of Austria. Generally, precipitation amounts are higher on the fringe of the Alps in northern Vorarlberg due to blockage effects of the inflowing air masses (Werner and Auer 2001a; Werner and Auer $2001 b)$. The Laternser valley opens up to the west and is therefore prone to north and north-westerly weather conditions. At Innerlaterns station (location mapped in Fig. 2), the mean annual precipitation exceeds $1700 \mathrm{~mm}$. In the study area, exceptional amounts of rainfall have been identified as the main trigger of shallow landslides (Andrecs et al. 2002; Markart et al. 2007).

\section{Landslide-triggering rainfall event on 22/23 August 2005}

Antecedent rainfall conditions from November 2004 on to the 22/ 23 August 2005 event generally fell below the long-term mean. Therefore, it can be expected that the antecedent soil moisture preceding the rainfall event was below average. Effects of snow can be excluded during the summer months. After days with minor rainfalls in mid-August, a phase of intense precipitation started on August 22. At Innerlaterns station, the cumulative precipitation sum of the rainfall event amounted to $256 \mathrm{~mm}$ (Fig. 2a). The highest rainfall intensity was recorded in the late evening on August 22 and during the night hours (21 to 22 p.m. $19.4 \mathrm{~mm} / \mathrm{h}$ ). With the help of multiple orthophoto series and two DTMs based on airborne laser scanning (ALS), a detailed shallow landslide inventory was prepared (Zieher et al. 2016; Fig. 2b). In total, 478 shallow landslides associated with the rainfall event in August 2005 were mapped.

\section{Materials and methods}

\section{Test sites and field work}

Geotechnical samples were collected at four sites where shallow landslides had been triggered in the course of the rainfall event in August 2005. The slope failures occurred during the night hours from 22/23 August. Therefore, hardly any eyewitness reports on 


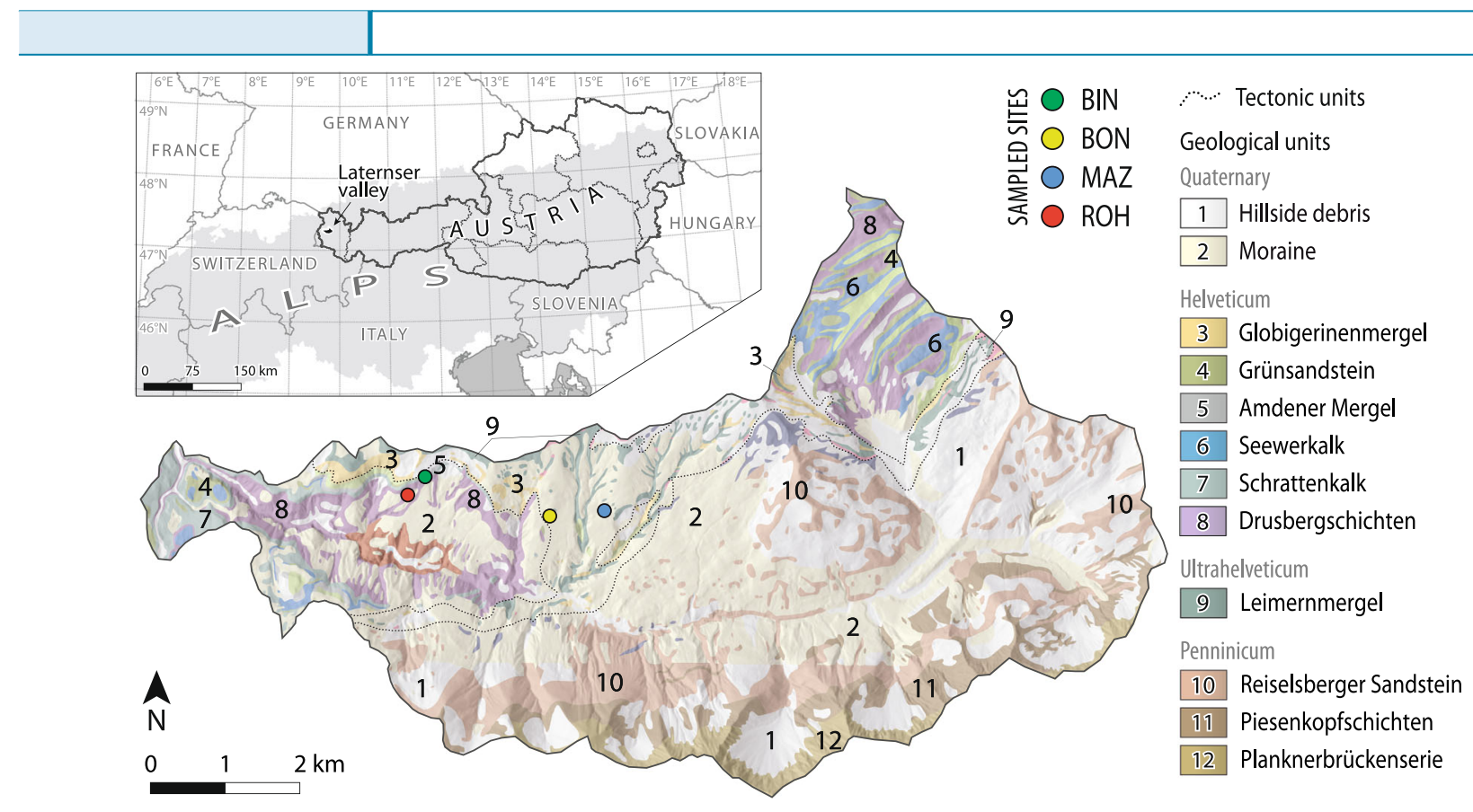

Fig. 1 Location of the Laternser valley and its geological substratum. Only geological units covering more than $1 \%$ of the valley are listed in the legend (modified after Zieher et al. 2016). Sampled landslide locations are mapped as dots

the exact time of failure are available throughout the valley. In the geological map (Fig. 1b), the sampled shallow landslide locations are mapped as hillslope debris (BIN), till deposits (BON, MAZ), and Drusbergschichten (marls with calcareous layers; ROH). These geological units have been identified as overly susceptible to shallow landsliding in the Laternser valley (Zieher et al. 2016). Particularly, the slope-parallel dipping marls of the Amdener Mergel (BIN), Leimernmergel (BON, MAZ), and Drusbergschichten $(\mathrm{ROH})$ provide potential sliding surfaces at the bedrock-regolith interface. Stabilizing effects of high vegetation can be excluded at the test sites BON and MAZ as these landslides occurred on extensively used grass land. In case of the slope failures at the test sites BIN and ROH, single trees above the scarp may have contributed to the stability of the slopes. The four landslides turned into debris avalanches (BIN, BON, MAZ) and a debris flow (ROH) with runout distances of up to $150 \mathrm{~m}$. Accumulated material on roads and within agricultural areas was removed subsequently.

Back walls were laid open at the scarp of the shallow landslides. The sampling strategy comprised two undisturbed and one disturbed sample at two depths at each site. At one site $(\mathrm{ROH})$, samples at one depth were considered sufficient due to the homogeneous structure of the regolith. Undisturbed samples were taken with a core cutter and stored airtight. In addition, one bucket of material was sampled at the respective depths. Samples obtained

Table 1 Metadata for the four sampled landslide sites and results of the conducted laboratory tests

\begin{tabular}{|c|c|c|c|c|}
\hline Parameters & BIN & BON & MAZ & $\mathrm{ROH}$ \\
\hline Latitude (degree) & 47.2722 & 47.2673 & 47.2679 & 47.2699 \\
\hline Longitude (degree) & 9.7040 & 9.7256 & 9.7352 & 9.7001 \\
\hline Scar area $\left(\mathrm{m}^{2}\right)$ & 437 & 363 & 1036 & 487 \\
\hline Sample depth 1 (cm) & 45 & 30 & 37 & - \\
\hline Sample depth $2(\mathrm{~cm})$ & 92 & 80 & 67 & 108 \\
\hline Depth of landslide crown (m) & 1.1 & 1.2 & 0.9 & 1.7 \\
\hline Angle of internal friction (degree) & 25.9 & 30.3 & 29.3 & 37.2 \\
\hline Cohesion (kPa) & 5.6 & 6.2 & 4.6 & 17.6 \\
\hline Plastic limit (mass \%) & 23.5 & 26.8 & 26.6 & 18.9 \\
\hline Liquid limit (mass \%) & 40.0 & 46.2 & 41.8 & 23.1 \\
\hline Dry density $\left(\mathrm{g} / \mathrm{cm}^{3}\right)$ & 1.36 & 1.37 & 1.45 & 1.99 \\
\hline Porosity (\%) & 46.3 & 48.9 & 45.1 & 25.5 \\
\hline Soil type & Clay; medium plastic & Clay; medium plastic & Silt; medium plastic & Clay/silt; slightly plastic \\
\hline
\end{tabular}




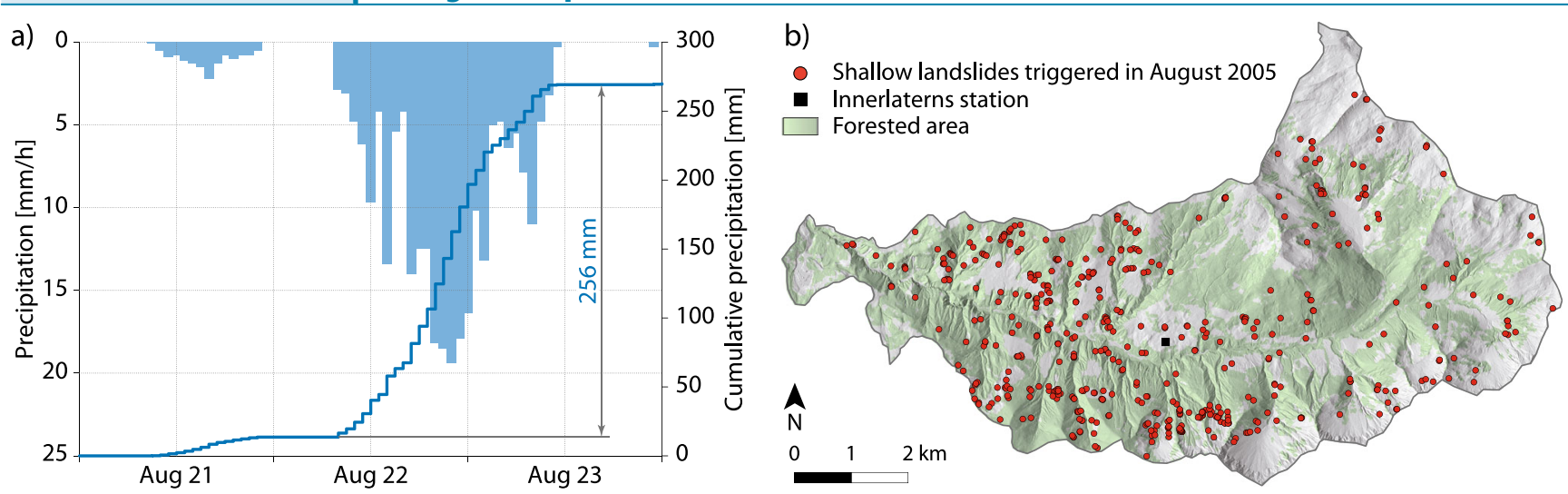

Fig. 2 Hourly and cumulative precipitation time series (Innerlaterns station) of the landslide-triggering rainfall event on 22/23 August 2005 as well as the inventory showing all mapped shallow landslides for this event (b). The location of Innerlaterns station is shown in $\mathbf{b}$

in the upper part of the back wall were used for the derivation of hydrological properties mainly. Lower samples were used for the estimation of geotechnical parameters (angle of internal friction, cohesion, Atterberg limits). Water contents, wet and dry bulk densities, as well as grain size distributions were determined for all samples. Figure 3 shows the grain size distributions and the Atterberg limits for the tested samples.

At test site BON, the regolith depth above the landslide scarp was assessed by dynamic cone penetration tests (DCPTs, locations mapped in Fig. 4). A lightweight dynamic cone penetrometer including a rammer of $10 \mathrm{~kg}$ dropped from a height of $0.5 \mathrm{~m}$ was used (e.g., Wiegand et al. 2013; Perumpral 1987). In accordance with (ÖNORM EN ISO 22476-2:2012 2012), the necessary number of strokes to penetrate through increments of $10 \mathrm{~cm}$ was recorded. If the vertical increment after completing 50 strokes was less than $10 \mathrm{~cm}$, the penetration tests were stopped (ÖNORM EN ISO 224762:2012 2012). The locations of the DCPTs were measured using a differential global positioning system (dGPS).

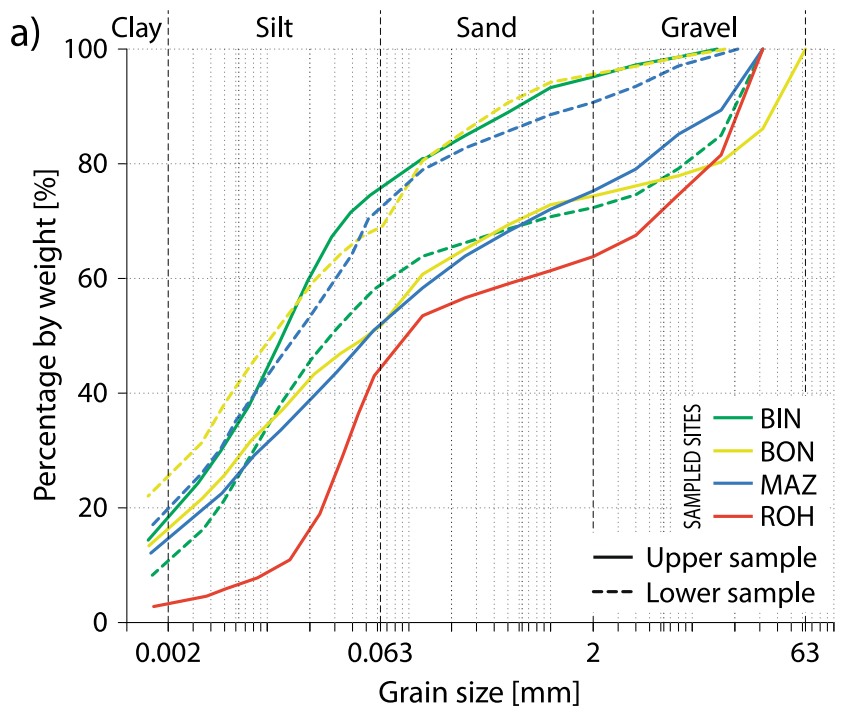

\section{Landslide geometry derived from multi-temporal airborne laser scanning}

For the study area, high-resolution DTMs of two ALS campaigns in 2004 ( $1.0 \mathrm{~m}$ cell size) and 2011 ( $0.5 \mathrm{~m}$ cell size) are available area-wide. The subtraction of both DTMs (differential digital terrain model; dDTM) yields the height difference between the times of acquisition. Shallow landslide scar areas are detectable as distinct features characterized by a decrease in elevation, i.e., a loss of volume (Fig. 4). Table 2 shows the reported point densities and accuracies of the two ALS campaigns conducted area-wide for the state of Vorarlberg. These numbers are minimum requirements which must be provided throughout the scanned area. Therefore, the acquired point density is typically higher. At the test sites, the actual point density for 2004 is between 1.9 and $5.0 \mathrm{pts} \mathrm{m}^{-2}$ while it is distinctively higher for 2011 with $15.4-19.5 \mathrm{pts}^{-2}$. Also the error margins, including systematic errors, positional uncertainty due to the size of the laser beams' footprints, and the registration error, must be

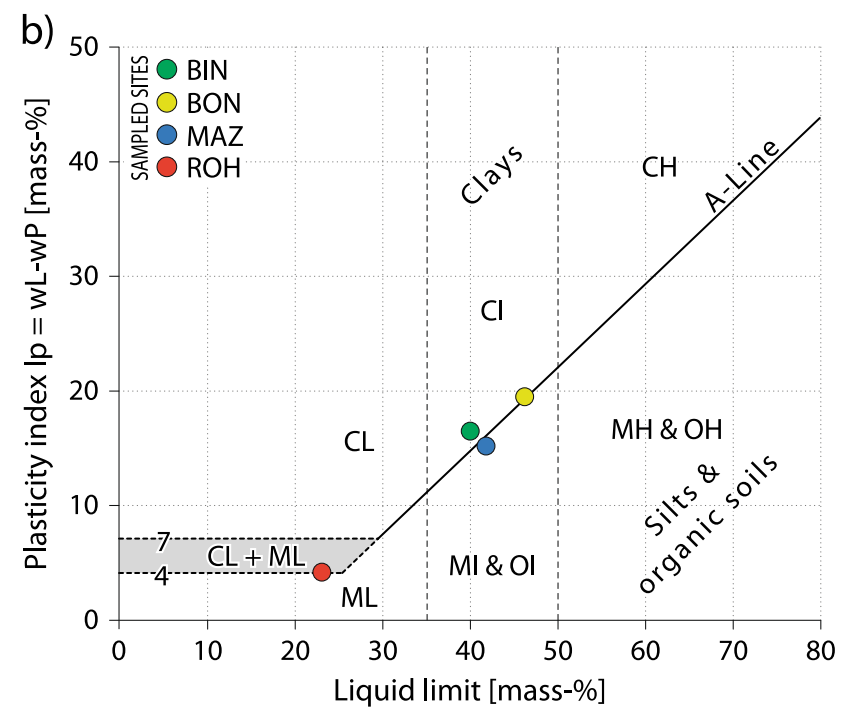

Fig. 3 Resulting grain size distributions (a) and Atterberg limits (b) for the tested samples 


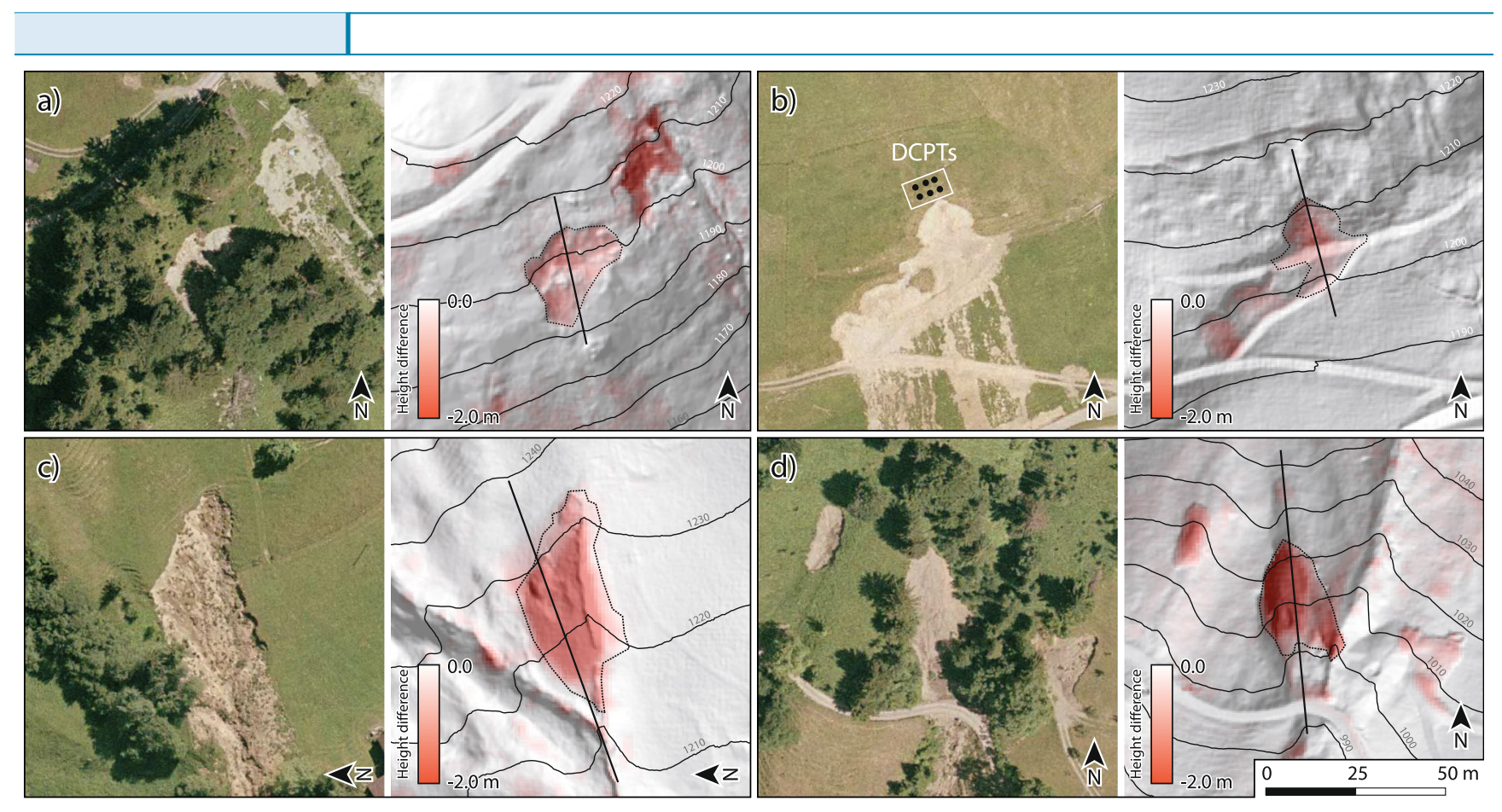

Fig. 4 Shallow landslide locations in the orthophoto of 2006 and in the DTM (shaded relief) of 2011 (a BIN, b BON, c MAZ, d ROH). Negative height differences (dDTM) are shown in red colours on top of the shaded reliefs. In $\mathbf{b}$, the locations of the conducted DCPTs above the scarp of the landslide at test site BON are mapped. Sections were cut along the black lines for 2D limit equilibrium analyses with Janbu's model. For the sake of comparability, the scale of the height difference shown in the shaded reliefs was adjusted to the same value range $(-2-0 \mathrm{~m})$

provided area-wide and are hence conservative. In addition, none of the scar areas at the test sites re-vegetated. Particularly, low vegetation would have an adverse impact on the positional accuracy. It has been therefore generally assumed that (i) the accuracies of the ALS point clouds are sufficient for accurately detecting landslide depths for the purpose of the present study and (ii) the morphology of the landslide scars is sufficiently represented by the derived raster datasets. In addition, it is presumed that the surface mainly changed due to shallow landsliding and further processes play a minor role.

Within the scar area, the dDTM gives an estimate of the vertical landslide depth (Fig. 5). Two landslides are rather shallow (BIN, BON) extending to a depth of $1.6 \mathrm{~m}$ while the other two are generally deeper (MAZ, ROH) with up to 3.3 and $4.5 \mathrm{~m}$, respectively. Regarding the type of movement, depth-to-length ratios are frequently used to differentiate between translational and rotational landslides (e.g., Cruden and Varnes 1996; Skempton and Hutchinson 1969). Translational landslides are characterized by a low depth-to-length ratio of typically less than 0.1 (Cruden and Varnes 1996). Based on this criterion, all four landslides are of the translational type (Table 3).
Slope angles derived from the first DTM provide estimates of the inclination of the original surface before the landslides occurred. The evaluation within the scar areas results in slope angle distributions (Fig. 6). Theoretically, slope angles within the scar areas derived from the second DTM show the inclination of the sliding surface. For the landslide locations BIN and BON, no significant changes of median and mean slope angles are noticeable while their variance increased. This can be attributed to the side walls of the landslides biasing the slope angle values within the scar area. For the landslide location MAZ, a slight increase and for location ROH, a slight decrease of median slope angles is evident. Compared to the pre-event surface, this could indicate a steeper sliding surface at test site MAZ and a less inclined sliding surface at test site ROH. However, these distributions show possible value ranges for the slope angle as input parameter for the ISSM. The slope angle distributions were calculated based on the tangent and are shown in degrees. Table 4 shows statistics of the slope angle distributions evaluated within the scar areas.

Figure 7 shows the real-world geometry of the four shallow landslides represented in the ADTM and principles of the landslide geometry considered in the three types of models. The ISSM and

Table 2 Metadata of the two ALS campaigns covering the state of Vorarlberg

\begin{tabular}{|lllll}
\hline ALS campaign & Point density demanded & $\begin{array}{l}\text { Reported accuracy } \\
\text { Horizontal }\end{array}$ & Vertical & Spatial resolution \\
\hline 2004 & 1 pt per $\mathrm{m}^{2}$ & - & $\pm 20 \mathrm{~cm}$ & $1.0 \mathrm{~m}$ \\
\hline 2011 & 4 pts per $\mathrm{m}^{2 \mathrm{a}}$ & $\pm 10 \mathrm{~cm}$ & $\pm 7.5 \mathrm{~cm}$ & $0.5 \mathrm{~m}$ \\
\hline
\end{tabular}

${ }^{a}$ In 2011, a minimum point density of 8 pts per $\mathrm{m}^{2}$ is provided in the vicinity of main rivers 


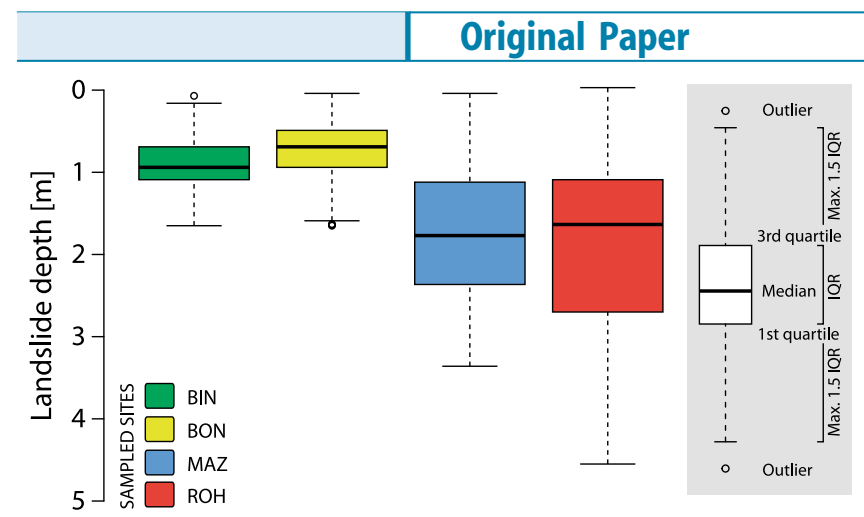

Fig. 5 Vertical landslide depth distribution of the four scar areas derived from the dDTM. Landslide depth is provided positive in downward direction. IQR interquartile range

Janbu's model are based on simplified approximations of the geometry. Only the $3 \mathrm{D}$ approaches include the details of locally varying landslide depth also in lateral direction.

\section{Infinite slope stability model}

The ISSM relies on a limit equilibrium approach relating stabilizing to destabilizing forces (Fig. 8). In the model, the landslide geometry is reduced to a slope-parallel layer of infinite length and width on top of an inclined, slope-parallel sliding surface (Fig. 7e). Assuming fully saturated conditions and slope-parallel ground water flow, the FOS is calculated from:

FOS $=\frac{T}{S}=\frac{c^{\prime} \cdot l+N^{\prime} \cdot \tan \phi^{\prime}}{W^{\prime} \cdot \sin \beta+F_{S}}$

where $c^{\prime}$ is the effective cohesion, $l$ is the unit length, $N^{\prime}$ is the effective normal force, $\phi^{\prime}$ is the effective angle of internal friction of the soil material, $W^{\prime}$ is the effective weight of saturated soil, $\beta$ is the slope angle, and $F_{s}$ is the seepage force. All forces are calculated as unit forces where the width corresponds to 1 unit length (e.g., Mergili et al. 2014; Fellin 2014; Ghiassian and Ghareh 2008). The model's formulae and the workflow for parameter testing were implemented in the $\mathrm{R}$ open source software environment for statistical computing (R Core Team 2016).

The results of the ISSM are highly sensitive to the parameters representing landslide geometry assumed by the model (i.e., slope angle and landslide depth). The model was applied for the four sampled landslide locations assuming the results of the laboratory tests to be representative for the local material characteristics. Based on the respective parameter values (i.e., specific weight, effective cohesion, and effective angle of internal friction; Table 1), the impact of landslide depth and slope angle is assessed in detail.

\section{Janbu's model}

The model after (Janbu 1954) follows the limit equilibrium concept and is based on polygonal sliding surfaces with longitudinal slices of defined lateral length and infinite width (Fig. 9). For the limit equilibrium, all forces acting on each single slice in its center of mass are taken into account. Compared to the ISSM, a more complex $2 \mathrm{D}$ geometry of the sliding surface can be reproduced (Fig. 7f). The landslide geometries of the four test sites were obtained from the available pre- and post-event DTMs along slope-parallel profiles (Fig. 10). The FOS was calculated using the software GGU-Stability (GGU 2016) employing the following formula:

$$
\mathrm{FOS}=\frac{\sum_{i}\left(T_{i}+E_{i}\right)}{\sum_{i}\left(S_{i}+E_{i+1}\right)}=\frac{\sum_{i}\left(c^{\prime} \cdot l_{i}+N_{i}^{\prime} \cdot \tan \phi^{\prime}+E_{i}\right)}{\sum_{i}\left(W_{i}^{\prime} \cdot \sin \beta_{i}+F_{s_{i}}+E_{i+1}\right)}
$$

where the sum of resisting forces $T_{i}$ and stabilizing forces from adjacent slices $E_{i}$ are related to the sum of driving forces $S_{i}$ and destabilizing forces from adjacent slices $E_{i+1}$ for each slice $i$. All forces are calculated as unit forces where the width corresponds to 1 unit length. $c^{\prime}$ is the effective cohesion, $l_{i}$ is the length of slice $i, N_{i}{ }^{\prime}$ is the effective normal force, $\phi^{\prime}$ is the effective angle of internal

Table 3 Statistics of landslide length and vertical depth distributions derived from dDTM evaluation within the scar areas

\begin{tabular}{|c|c|c|c|c|}
\hline Vertical depth (m) & BIN & BON & MAZ & $\mathrm{ROH}$ \\
\hline Minimum & 0.07 & 0.04 & 0.04 & 0.03 \\
\hline First decile & 0.51 & 0.29 & 0.69 & 0.79 \\
\hline First quartile & 0.69 & 0.49 & 1.12 & 1.09 \\
\hline Median & 0.94 & 0.69 & 1.77 & 1.63 \\
\hline Mean & 0.90 & 0.73 & 1.74 & 1.92 \\
\hline Third quartile & 1.09 & 0.94 & 2.36 & 2.69 \\
\hline Ninth decile & 1.27 & 1.23 & 2.73 & 3.53 \\
\hline Maximum & 1.65 & 1.65 & 3.36 & 4.55 \\
\hline Length (m) & 31.1 & 29.5 & 68.0 & 47.2 \\
\hline $\mathrm{D} / \mathrm{L}$ ratio & 0.047 & 0.050 & 0.046 & 0.075 \\
\hline
\end{tabular}

Vertical landslide depth is provided positive in downward direction. Depth-to-length ratios are based on the maximum depth perpendicular to the slope and planimetric landslide length corrected by the mean slope angle within the scar area 


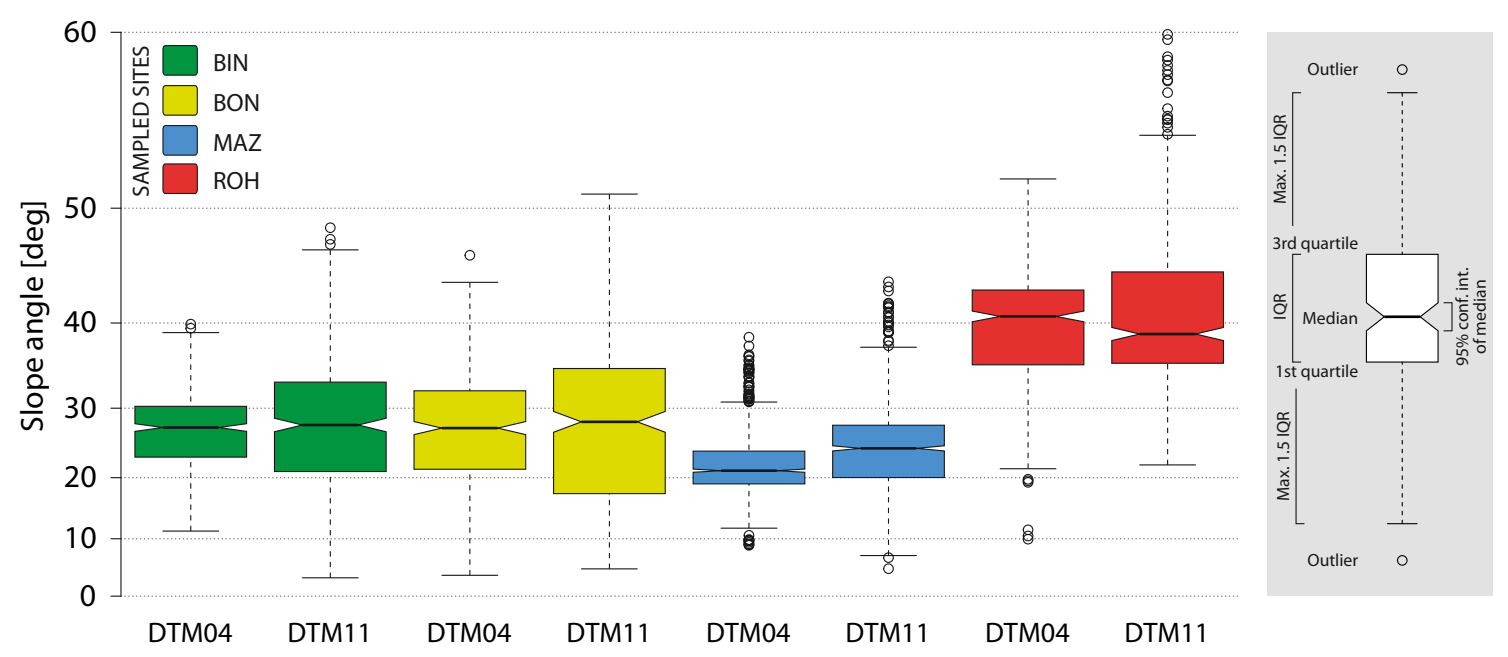

Fig. 6 Slope angle distributions (tangent) within the four scar areas derived from two DTMs. The second DTM (2011) was coregistrated with the first DTM (2004) and therefore resampled to $1 \mathrm{~m}$ spatial resolution. The notches suggest a significant shift of median slope angles for the locations MAZ and ROH. Slope angles were calculated after (Horn 1981) using the r.slope.aspect module of GRASS GIS 6.4 with a neighborhood of 3px. IQR interquartile range

friction, $E_{i}$ is a stabilizing force resulting from the passive earth pressure exerted by the slice below, $W_{i}^{\prime}$ is the slice's weight of saturated soil, $F_{s_{i}}$ is the seepage force, and $E_{i+1}$ is a destabilizing force resulting from the active earth pressure exerted by the slice above.

\section{D approaches}

The r.slope.stability model (Mergili et al. 2014) evaluates the slope stability conditions for one to many randomly selected ellipsoidal sliding surfaces. By default, the longest half axis is aligned along the steepest slope. The ellipsoids can be truncated in order to consider irregular sliding surfaces such as the bottom of soil, shallow weak layers, or shallow discontinuities bounded by hard bedrock. To compute the FOS, r.slope.stability employs a modified version of the 3D sliding surface model of (Hovland 1977), revised and extended by (Xie et al. 2006; Xie et al. 2003; Xie et al. 2004a; Xie et al. 2004b):

$$
\text { FOS }=\frac{\sum_{i} T}{\sum_{i} S}=\frac{\sum_{i}\left(c^{\prime} \cdot a_{i}+\left(W_{i}^{\prime} \cdot \cos \beta_{i}+N_{s_{i}}\right) \cdot \tan \phi^{\prime}\right) \cdot \cos \beta_{m_{i}}}{\sum_{i}\left(W_{i}^{\prime} \cdot \sin \beta_{m_{i}}+F_{s_{i}}\right) \cdot \cos \beta_{m_{i}}}
$$

where $a_{i}$ is the basal area of each soil column derived from

$a_{i}=s_{c}^{2} \cdot \frac{\sqrt{1-\left(\sin ^{2} \beta_{x z_{i}} \cdot \sin ^{2} \beta_{y z_{i}}\right)}}{\cos \beta_{x z_{i}} \cdot \cos \beta_{y z_{i}}}$

where $s_{c}$ is the cell size for squared raster cells, $\beta_{x z_{i}}$ is the slope angle component in east-west direction, and $\beta_{y z_{i}}$ is the slope angle component in north-south direction (Xie et al. 2003). In Eq. 3, resisting forces T and driving forces $S$ are summed over all columns $i$ within the scar area. $c^{\prime}$ is the effective cohesion per unit area, $W_{i}^{\prime}$ is the effective weight of saturated soil, $\beta_{i}$ is the inclination of the sliding surface at the considered column, $\phi^{\prime}$ is the effective angle of internal friction, and $\beta_{m_{i}}$ is the apparent dip of the sliding surface at the considered column in downslope direction (alignment of the ellipsoid). $N_{s}$ and $F_{s}$ are the contributions of the seepage force to the normal force and the shear force. No inter-column forces are considered. The principles of the FOS calculation are discussed in detail by (Mergili et al. 2014). r.slope.stability further includes several functionalities to combine the FOS values computed for various sliding surfaces to landslide susceptibility maps (Mergili et al. 2014). In the present work, however, single truncated sliding surfaces are used, corresponding to the sliding surfaces of the considered shallow landslides.

A simplified $3 \mathrm{D}$ volumetric approach (3DVA) is based on discrete soil columns represented in a raster environment assuming slope-parallel ground water flow (Fig. 11). In contrast to r.slope.stability, considering a main direction of the slope failure for the calculation of driving and resisting forces, all forces are calculated for each column based on its inclination and aspect. The FOS is the ratio of the sums of resisting forces $T_{i}$ and driving forces $S_{i}$ for all columns $i$ within the scar area:

$\operatorname{FOS}=\frac{\sum_{i} T_{i}}{\sum_{i} S_{i}}=\frac{\sum_{i}\left(c^{\prime} \cdot a_{i}+N_{i}^{\prime} \cdot \tan \phi^{\prime}\right)}{\sum_{i}\left(W_{i}^{\prime} \cdot \sin \beta_{i}+F_{s_{i}}\right)}$

where $c^{\prime}$ is the effective cohesion per unit area and $a_{i}$ is the basal area of each soil column derived from Eq. 4. The slope angle components $\beta_{x z_{i}}$ and $\beta_{y z_{i}}$ were computed after (Horn 1981). The effective weight of saturated soil $W_{i}^{\prime}$ and the effective normal force are calculated based on each column's volume. $\phi^{\prime}$ is the effective angle of internal friction, $\beta_{i}$ is the inclination of the sliding surface at the considered column, and $F_{s_{i}}$ is the seepage force. Effects of active and passive earth pressure are neglected.

\section{Results and discussion}

Table 5 shows the resulting values of the FOS for the test sites based on the four tested slope stability models assuming dry and 
Original Paper

Table 4 Statistics of the slope angle distributions evaluated within the scar areas of the four shallow landslides for the two DTMs

\begin{tabular}{|c|c|c|c|c|c|c|c|c|}
\hline $\begin{array}{l}\text { Slope angle } \\
\text { (degree) }\end{array}$ & $\begin{array}{l}\text { BIN } \\
\text { DTM } \\
2004\end{array}$ & $\begin{array}{l}\text { DTM } \\
2011\end{array}$ & $\begin{array}{l}\text { BON } \\
\text { DTM } \\
2004\end{array}$ & $\begin{array}{l}\text { DTM } \\
2011\end{array}$ & $\begin{array}{l}\text { MAZ } \\
\text { DTM } \\
2004\end{array}$ & $\begin{array}{l}\text { DTM } \\
2011\end{array}$ & $\begin{array}{l}\text { ROH } \\
\text { DTM } \\
2004\end{array}$ & $\begin{array}{l}\text { DTM } \\
2011\end{array}$ \\
\hline Minimum & 11.3 & 3.2 & 3.7 & 4.8 & 8.9 & 4.8 & 9.9 & 22.0 \\
\hline First decile & 18.5 & 14.9 & 10.1 & 9.5 & 17.4 & 17.4 & 31.9 & 32.5 \\
\hline First quartile & 23.1 & 21.0 & 21.3 & 17.5 & 19.0 & 20.0 & 35.4 & 35.6 \\
\hline Median & 27.4 & 27.7 & 27.3 & 28.2 & 21.1 & 24.4 & 40.7 & 38.8 \\
\hline Mean & 26.7 & 27.9 & 26.7 & 27.5 & 22.0 & 24.4 & 39.7 & 41.5 \\
\hline Third quartile & 30.2 & 33.3 & 32.2 & 35.0 & 24.0 & 27.7 & 43.2 & 44.9 \\
\hline Ninth decile & 32.8 & 38.8 & 37.0 & 39.3 & 27.7 & 29.6 & 46.3 & 50.9 \\
\hline Maximum & 39.9 & 48.5 & 46.3 & 51.0 & 38.5 & 44.0 & 52.0 & 64.7 \\
\hline
\end{tabular}

Statistics are based on tangent and shown in degrees

fully saturated conditions. For the calculations using the ISSM, the median and maximum landslide depths were considered. Assuming dry conditions, all test sites are predicted to be stable by all models. Resulting values for the FOS are well above 1.0 ranging from 1.35 (ISSM; ROH) to 3.48 (r.slope.stability; BON). Considering fully saturated conditions, all test sites are predicted to fail by the ISSM using maximum landslide depths while only at test site MAZ the FOS falls below 1.0 using median landslide depths. Based on Janbu's model, two slopes would fail and no slope failures are predicted by the $3 \mathrm{D}$ approaches. The resulting values for the FOS are between 0.78 (ISSM; MAZ) and 2.15 (RSS; BON). Based on median landslide depths, all test sites except MAZ remain stable. In the following, the results for each modelling approach are described in detail.

\section{Modelling results using the ISSM}

Simulations based on median landslide depths result in more stable conditions predicted by the ISSM than for maximum landslide depths. The FOS for dry conditions using the ISSM based on median landslide depths in decreasing order is $2.70(\mathrm{BON}), 2.07$ (ROH), 2.01 (BIN), and 1.72 (MAZ), compared to 1.76 (BON), 1.54 (BIN), 1.49 (MAZ), and 1.35 (ROH) for simulations with maximum landslide depths. Assuming fully saturated conditions, all test sites are predicted to fail by the ISSM using maximum landslide depths. Based on median depths, all test sites except MAZ remain stable. The FOS for fully saturated conditions using the ISSM based on medium landslide depths in decreasing order is 1.69 (BON), 1.52 (ROH), 1.23 (BIN), and 0.96 (MAZ), compared to 0.99 (BON), 0.88 $(\mathrm{ROH}), 0.88(\mathrm{BIN})$, and 0.78 (MAZ) for simulations with a)
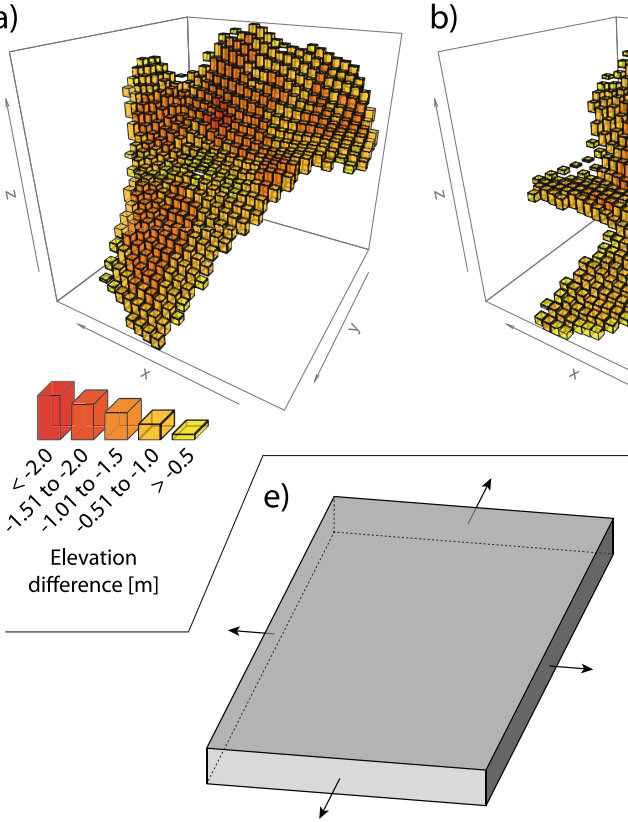

b)

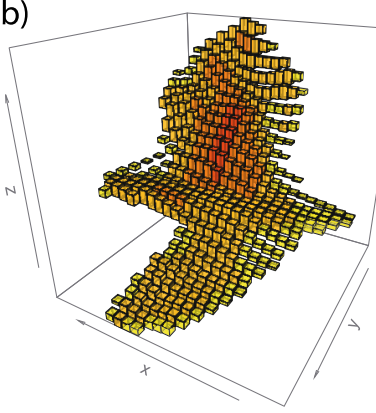

c)

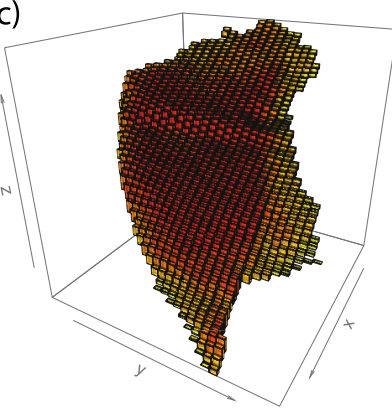

d)

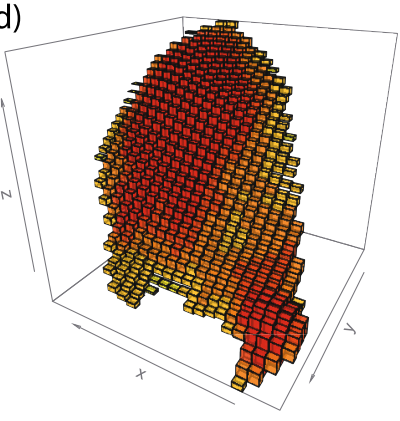

Fig. 7 Classified elevation difference between the two ALS-derived DTMs representing shallow landslide geometry at the sampled sites (a BIN, b BON, c MAZ, $\mathbf{d}$ ROH). Landslide geometry as represented in the infinite slope stability model (e), Janbu'smodel (f), and in a 3D model (g). The geometrical representations in (e), (f), and (g) are schematic sketches. For the calculations, their size is adjusted to the spatial resolution of the dDTM 


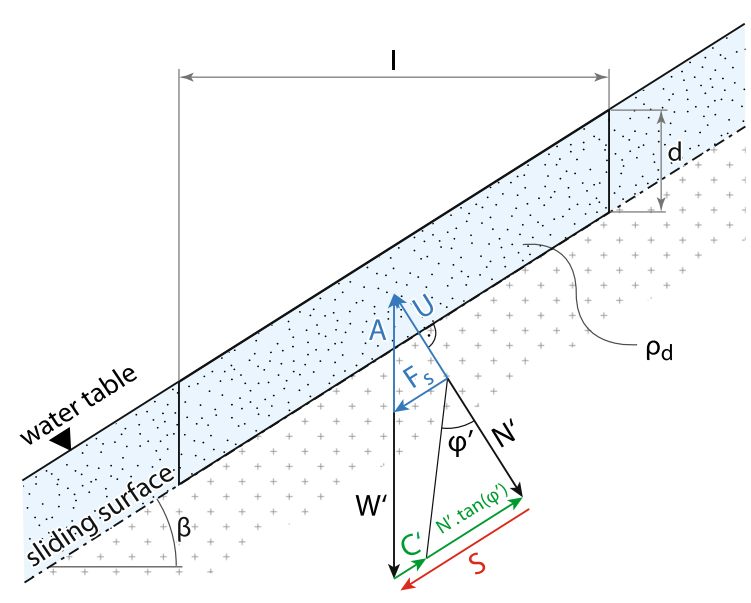

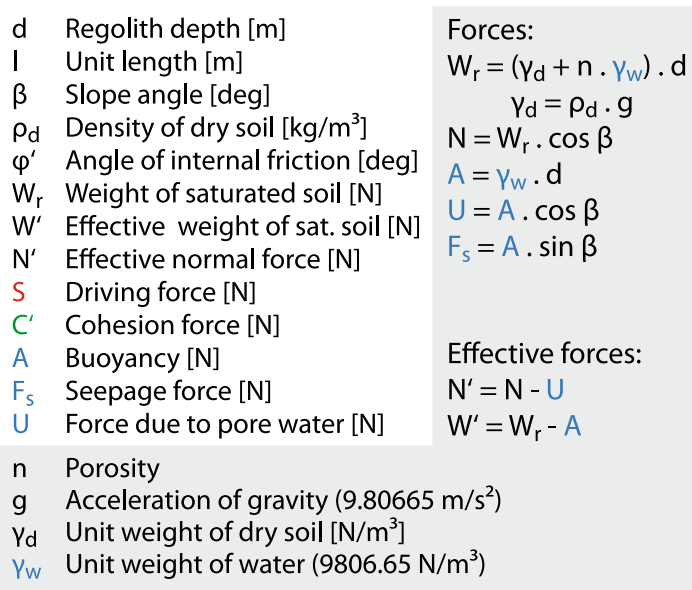

Fig. 8 Principle sketch of the ISSM for fully saturated and limit equilibrium conditions

maximum landslide depths. The ratios between FOS values based on median depths for dry and fully saturated conditions are 1.63 (BIN), 1.60 (BON), 1.79 (MAZ), and $1.36(\mathrm{ROH})$. The respective ratios using the maximum landslide depths are 1.75 (BIN), 1.78 (BON), 1.91 (MAZ), and $1.54(\mathrm{ROH})$. The latter are higher due to the effects of cohesion. At shallower depths, the stabilizing effect of cohesion is markedly higher than further below (see the "Conclusions" section).

\section{Modelling results using Janbu's model}

For dry conditions, none of the test sites are predicted to fail using Janbu's model. The resulting FOS values for Janbu's model in decreasing order are 2.28 (BON), 1.90 (MAZ), 1.81 (BIN), and 1.55 $(\mathrm{ROH})$. Compared to the results based on the ISSM using the maximum depths, the FOS for Janbu's model is higher by ratios of 1.18 (BIN), 1.30 (BON), 1.28 (MAZ), and 1.15 (ROH). Assuming fully saturated conditions, the slopes at the test sites MAZ and $\mathrm{ROH}$ are predicted to fail while test sites BIN and BON remain stable. The resulting FOS values in decreasing order are 1.38 (BON), 1.09 (BIN), 0.98 (MAZ), and $0.84(\mathrm{ROH})$. In case of test site $\mathrm{ROH}$, the FOS based on Janbu's model (o.84) is lower than that of the ISSM using the maximum landslide depth (o.88). Considering fully saturated conditions, the ratios of the resulting FOS based on Janbu's model and the ISSM using maximum landslide depths are $1.24(\mathrm{BIN}), 1.39(\mathrm{BON}), 1.26$ (MAZ), and $0.95(\mathrm{ROH})$.

\section{Modelling results using 3D approaches}

Both 3D models predict stable slopes at all four test sites for dry and fully saturated conditions. For dry conditions, the FOS values based on the 3DVA in decreasing order are 3.08 (BON), 2.30 (BIN), $2.22(\mathrm{ROH})$, and 1.85 (MAZ). Resulting FOS values for RSS are well above 2.0 with 3.48 (BON), 3.06 (MAZ), 2.68 (BIN), and 2.15 (ROH). Only in case of test site $\mathrm{ROH}$ the FOS is slightly lower based on RSS (2.15) compared to the 3DVA (2.22). The maximum ratios of the FOS assuming dry conditions for each test site between the results of the ISSM for maximum depth and the respective $3 \mathrm{D}$ approach are $1.74\left(\mathrm{BIN} ; \mathrm{FOS}_{R S S} / \mathrm{FOS}_{I S S M}\right), 1.98$ $\left(\mathrm{BON} ; \mathrm{FOS}_{R S S} / \mathrm{FOS}_{I S S M}\right), 2.05\left(\mathrm{MAZ} \mathrm{FOS}_{R S S} / \mathrm{FOS}_{I S S M}\right)$ and 1.64 $\left(\mathrm{ROH} ; \mathrm{FOS}_{3 D V A} / \mathrm{FOS}_{I S S M}\right)$. Assuming fully saturated conditions, respective FOS values for the 3DVA in decreasing order are 1.95 (BON), $1.67(\mathrm{ROH}), 1.44$ (BIN), and 1.04 (MAZ). Except for location ROH (1.60), the FOS based on RSS is higher with 2.15 (BON), 1.63 (BIN), and 1.71 (MAZ) compared to that of the 3 DVA. The maximum ratios of the FOS assuming fully saturated conditions for each test site between the results of the ISSM for maximum depth and the respective $3 \mathrm{D}$ approach are $1.85\left(\mathrm{BIN} ; \mathrm{FOS}_{\text {RSS }} / \mathrm{FOS}_{I S S M}\right)$,
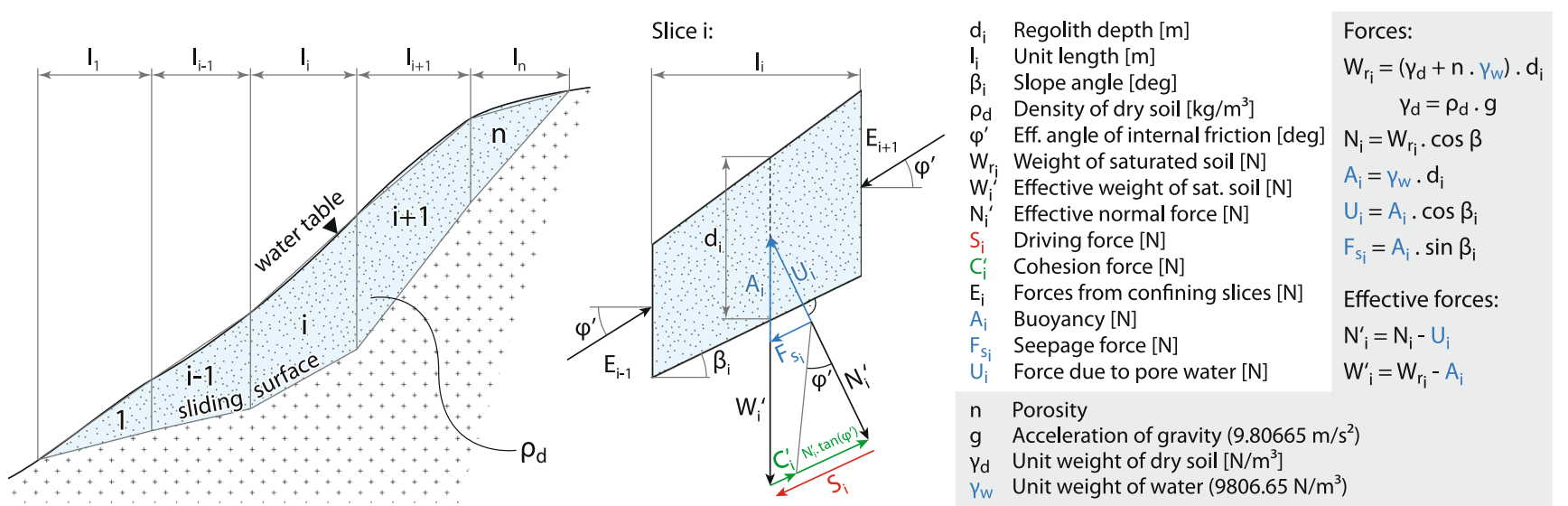

Fig. 9 Principle sketch of the slope stability model after (Janbu 1954) for fully saturated and limit equilibrium conditions 

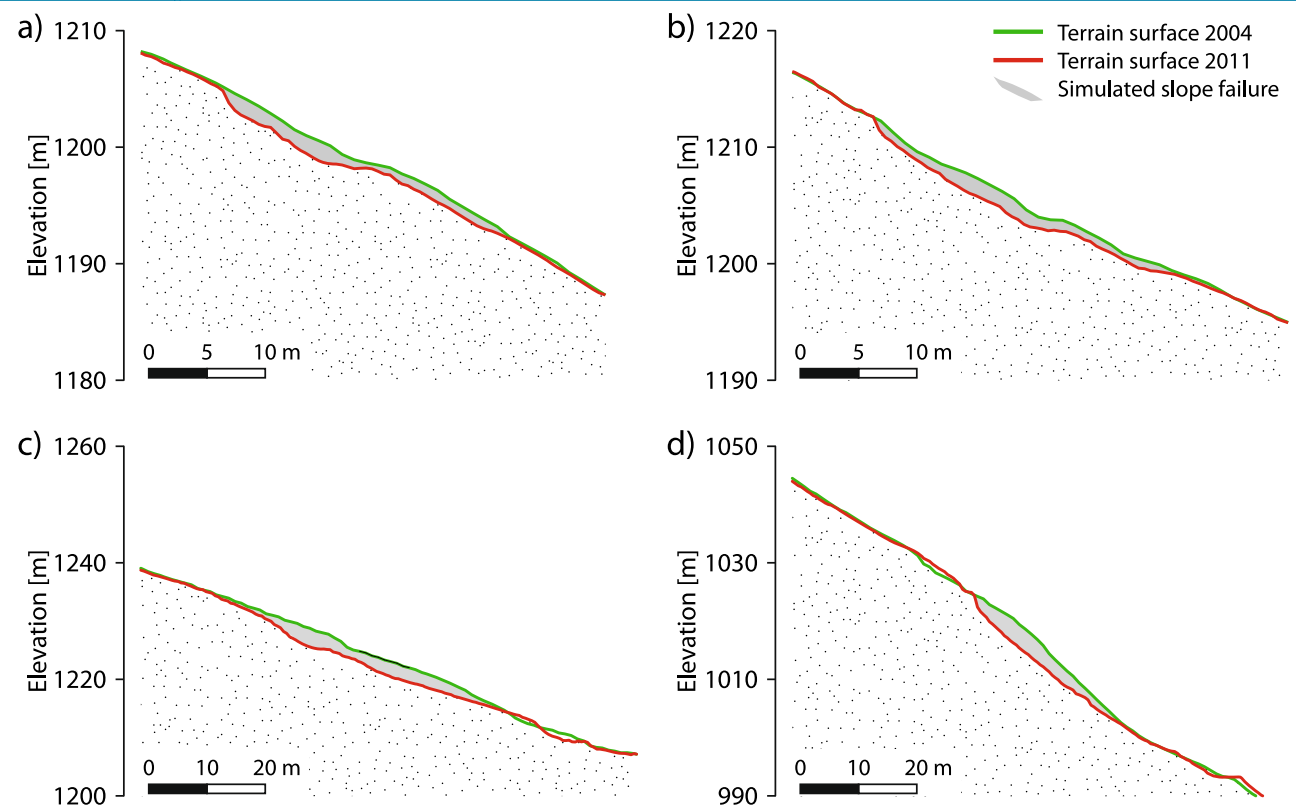

Fig. 10 Landslide profiles for calculations with Janbu's approach at the four test sites (a BIN, b BON, c MAZ, d ROH). The considered slope failures represented by the difference of the two DTMs are shown in grey

$2.17\left(\mathrm{BON} ; \mathrm{FOS}_{R S S} / \mathrm{FOS}_{I S S M}\right), 2.19\left(\mathrm{MAZ} ; \mathrm{FOS}_{R S S} / \mathrm{FOS}_{I S S M}\right)$, and 1.90 (ROH; $\left.\mathrm{FOS}_{3 D V A} / \mathrm{FOS}_{I S S M}\right)$. Hence, compared to the ISSM, slope stability (the FOS) is overestimated by the $3 \mathrm{D}$ models by a factor of around 2.

\section{Comparison of the results obtained with the various models}

Considering maximum landslide depth, the ISSM yields generally lower FOS compared to the $2 \mathrm{D}$ and $3 \mathrm{D}$ approaches for either dry or fully saturated conditions. Still, all four test sites were predicted correctly only by the ISSM. Calculations based on the maximum landslide depth indicate stable slopes under dry conditions and slope failures under fully saturated conditions. However, using the maximum landslide depth, the ISSM's simplified landslide geometry leads to a general overestimation of landslide depth. Hence, also, landslide volumes are overestimated.
Using Janbu's model, two of four test sites are predicted correctly. At test sites $\mathrm{MAZ}$ and $\mathrm{ROH}$, slope failures are predicted assuming fully saturated while slopes at test sites BIN and BON are predicted to remain stable. Compared to the results of the ISSM, the FOS is generally higher. Only in case of test site $\mathrm{ROH}$, the resulting FOS for fully saturated conditions based on Janbu's model is slightly lower than the corresponding FOS calculated with the ISSM.

Except for location MAZ, the resulting FOS using the $3 \mathrm{DVA}$ is distinctively higher than FOS values based on the ISSM or Janbu's model assuming dry conditions. The FOS using RSS is higher than resulting FOS based on the 3DVA except for location ROH. Resulting FOS values for both $3 \mathrm{D}$ approaches are higher than FOS values based on the ISSM and Janbu's model assuming fully saturated conditions. Although landslide geometry is represented
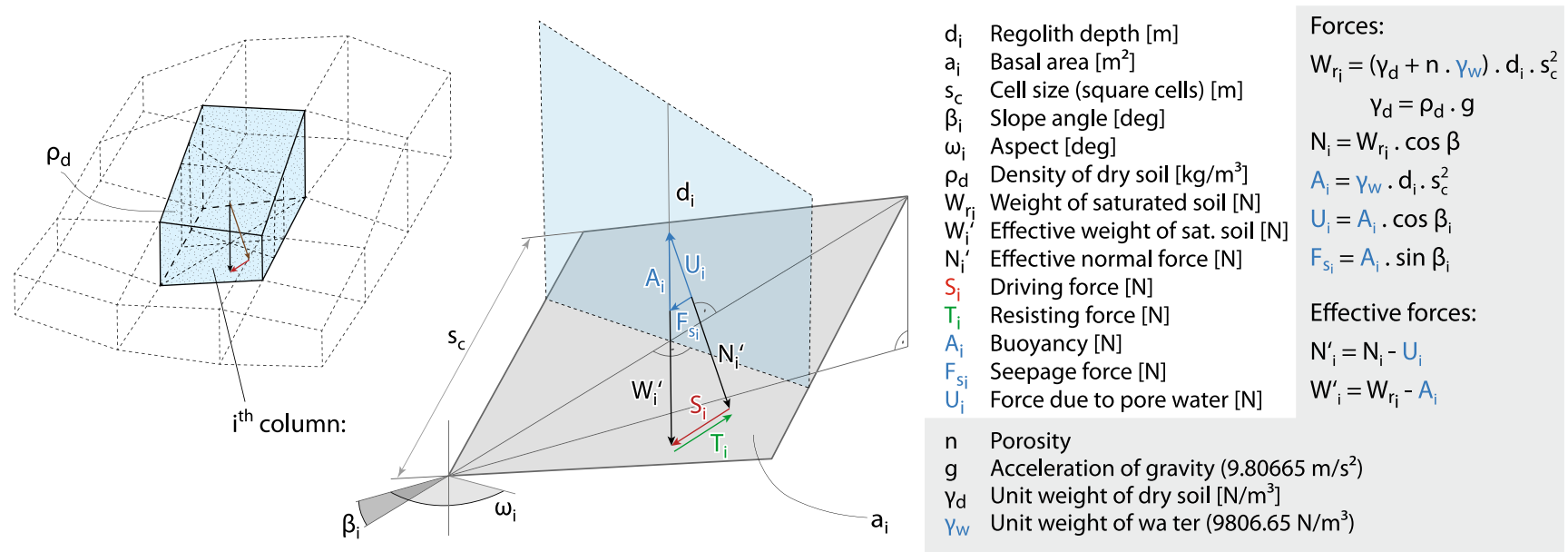

Fig. 11 Principle sketch of the 3D slope stability model for fully saturated conditions 


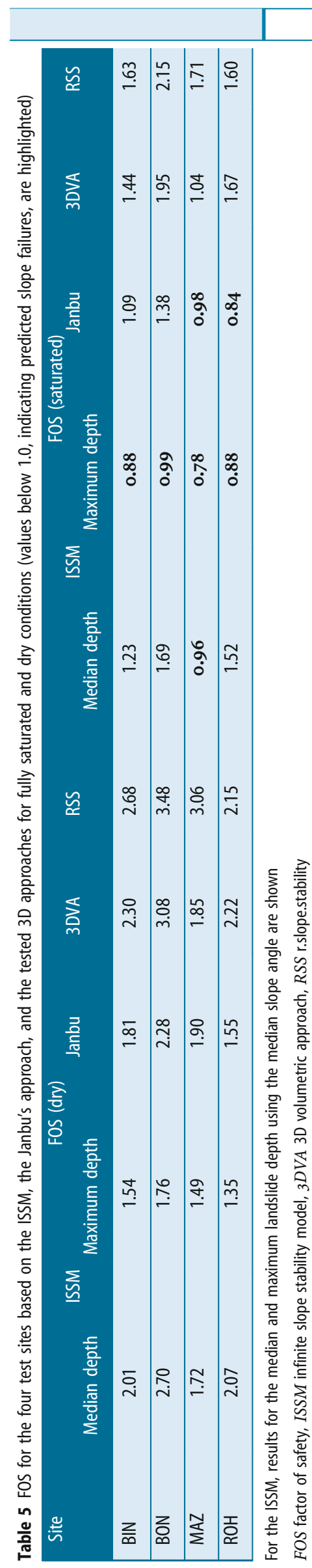

most accurately by the $3 \mathrm{D}$ models, both fail to predict any slope failure correctly with the applied parameterization. A possible reason for the inability of the $2 \mathrm{D}$ and $3 \mathrm{D}$ models to predict the slope failures is the influence of the cohesion in the shallow parts of the landslides. The impact of the cohesion on the resulting FOS decreases non-linearly with depth. Deeper parts of the landslides are predicted to fail with FOS $<1$ when considering single pixels, but the whole landslides are predicted to be stable. Including the shallower parts of the landslides in the calculation will enhance the overall FOS (Fig. 12).

In addition, geotechnical parameter values may have been overestimated. For an appropriate determination of the shear parameters, it is important to conduct the shear tests at in situ stress levels. The shear tests have been conducted at the lowest stress levels technically possible $(50 \mathrm{kPa})$. Nevertheless, the in situ stress level of shallow landslides might lie beyond this level (o$40 \mathrm{kPa}$ ). This may lead to an overestimation of the cohesion and a slight underestimation of the angle of internal friction for very shallow landslides. Furthermore, single parameter values cannot reflect the local variability of involved material properties.

\section{Effects of landslide geometry parameters in the ISSM}

Effects of the representation of landslide geometry in the ISSM on the resulting FOS are tested in more detail. Principal sketches describing the effects of landslide depth and slope angle on the FOS are shown in Fig. 13. The cumulative distribution of landslide depths shows the proportion of the landslide scar related to a certain depth (e.g., 20\% are deeper than $2.3 \mathrm{~m}$ ). The cumulative slope angle distribution shows the proportion of the landslide scar related to a certain slope angle (e.g., $60 \%$ are steeper than $18^{\circ}$ ). If stability analyses include a cohesion force, the FOS generally decreases non-linearly with depth (Fig. 14). Assuming fully saturated conditions and spatially constant material parameters, the depth of failure can be assessed (FOS falls below 1.0) for various slope angles. Figure 14 shows the FOS as a function of depth for a range of slope angle values derived from the DTM 2011 within the scar areas (Table 4). The depth of failure is compared to the cumulative distribution of landslide depths derived from the dDTM. At least a portion of each shallow landslide is deep enough to fall below a FOS of 1.0 considering the median slope angle (BIN $8.5 \%$, BON 0.3\%, MAZ 56.6\%, ROH 10.9\%). The affected parts are shown in the respective shaded relief. In case of the test sites MAZ and $\mathrm{ROH}$, the area falling below a FOS of 1.0 based on the median slope angle is well connected within the scar area. On the contrary, at test site BIN, the respective area is fragmented and distributed over the scar area.

In the same sense, the FOS decreases non-linearly with increasing slope angle (Fig. 15). Based on a range of landslide depth values evaluated within the scar area (Table 3), the critical slope angle for slope failure (FOS falls below 1.0) is derived and compared to the cumulative distribution of slope angles. The affected areas per depth are shown in the respective shaded relief. Parts of the suspected sliding surface of the locations BIN and MAZ are steep enough for the landslide to fail at median depth (BIN $13.7 \%$, MAZ $57.6 \%$ ). At the location $\mathrm{ROH}, 20.4 \%$ and $54.1 \%$ of the scar area are sufficiently inclined to fail at the third quartile and at the ninth decile of landslide depth, respectively. At the location BON, $1.9 \%$ and $30.2 \%$ of the scar area are sufficiently inclined to fail at the third quartile and at the ninth decile of landslide depth, 


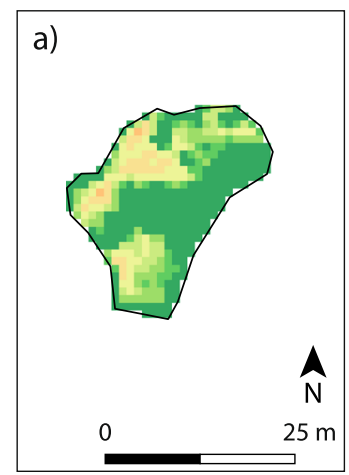

b)

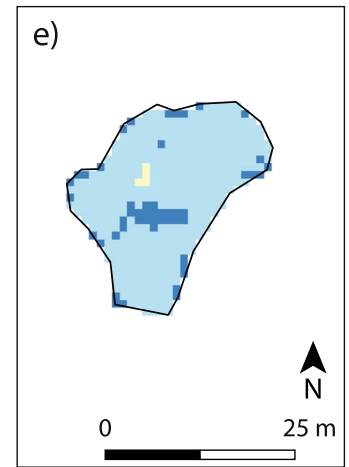

f) c)
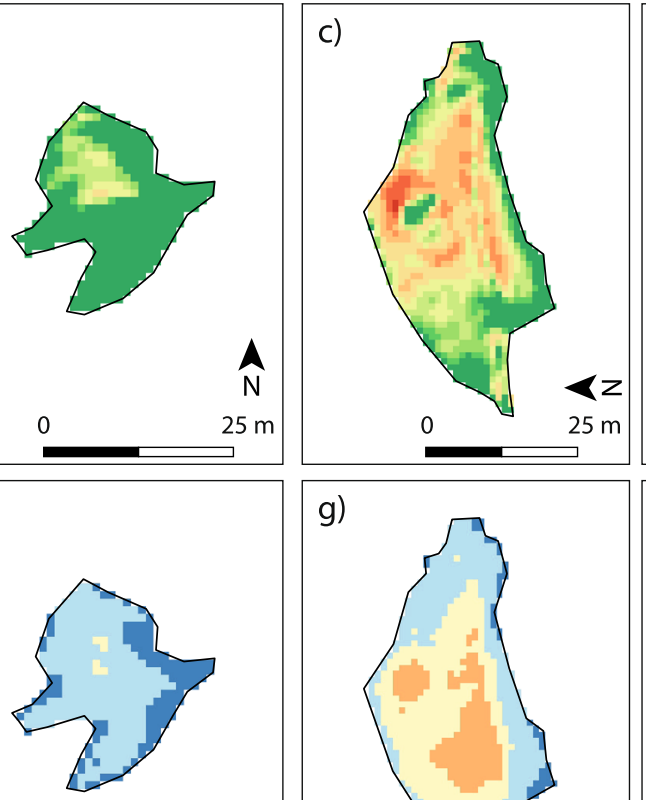

g)

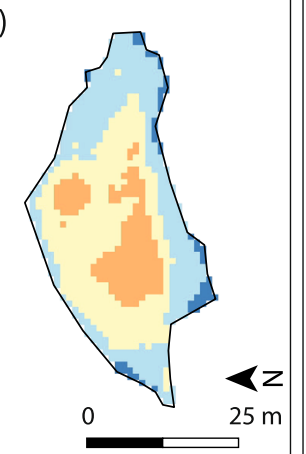

d)

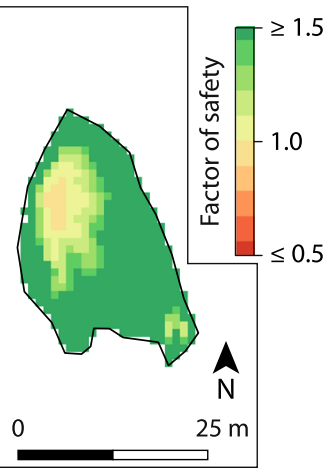

h)

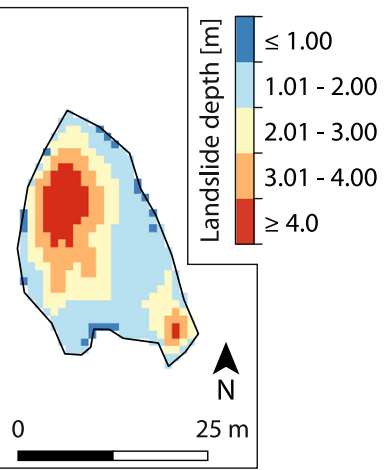

Fig. 12 Detailed results of the 3DVA model showing the calculated FOS (a-d) and the classified landslide depth derived from the dDTM (e-h) of each raster cell for the locations BIN (a, e), BON (b, f), MAZ (c, g), and ROH (d, h). Parts of each landslide show a FOS $<1$

respectively. However, the side walls of the landslides are generally steeper and should not be considered a potential sliding surface.

The ISSM predicts slope failures for parts of all sampled landslide locations. However, according to the ISSM, the location BON almost remains stable even under fully saturated conditions. The parameters representing the landslide geometry in the model could lead to an overestimation of slope stability. The slope angle distribution is known from the DTMs and is considered representative. In Fig. 16b, the penetration resistance and the regolith depth resulting from the DCPTs are compared with the landslide depth derived from the dDTM. Assuming that the underlying Leimernmergel had been reached, regolith depth ranges from 1.5 to $2.7 \mathrm{~m}$ in the vicinity of the landslide. Below $1.5 \mathrm{~m}$, the penetration resistance increases markedly. This could indicate an overconsolidated layer or a blocky matrix. The maximum landslide depth of $1.65 \mathrm{~m}$ derived from the dDTM within the scar area coincides with the depth below which penetration resistance increases. Hence, the sliding surface may be located on top of this overconsolidated layer. However, it cannot be completely ruled out that the landslide was originally deeper and hence would yield a lower FOS using the ISSM.

\section{Conclusions}

In the present study, four physically-based models including different representations of landslide geometry were tested to back calculate real-world slope failures. For the ISSM, the determining parameters for landslide geometry (i.e., slope angle and vertical landslide depth) were tested over ranges derived from DTMs a)

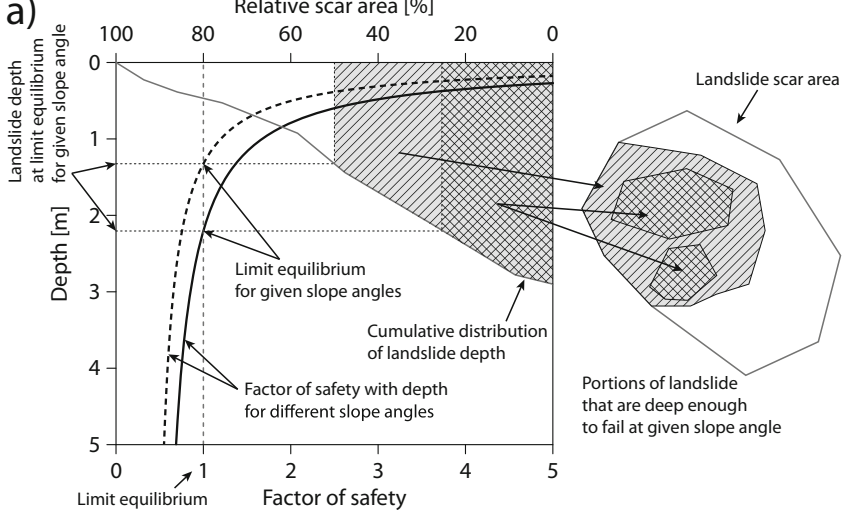

b)

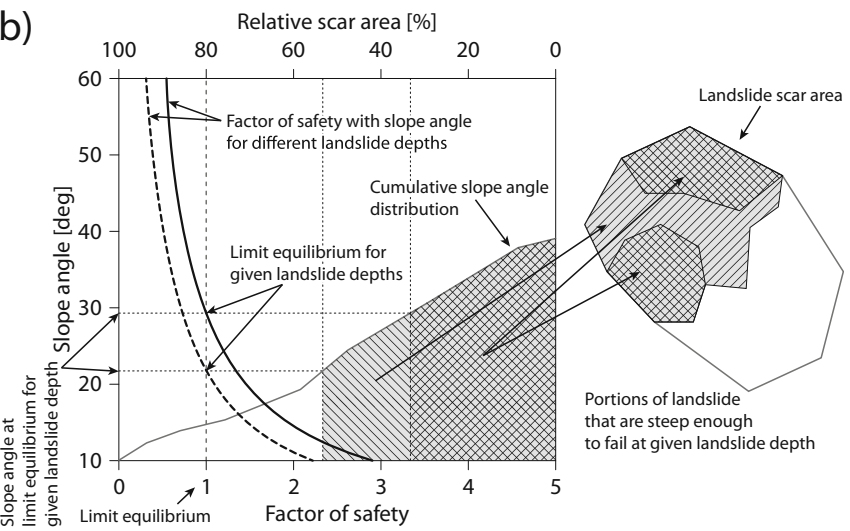

Fig. 13 Principal sketch of the impact analysis of landslide depth (a) and slope angle (b) on the FOS based on the ISSM 


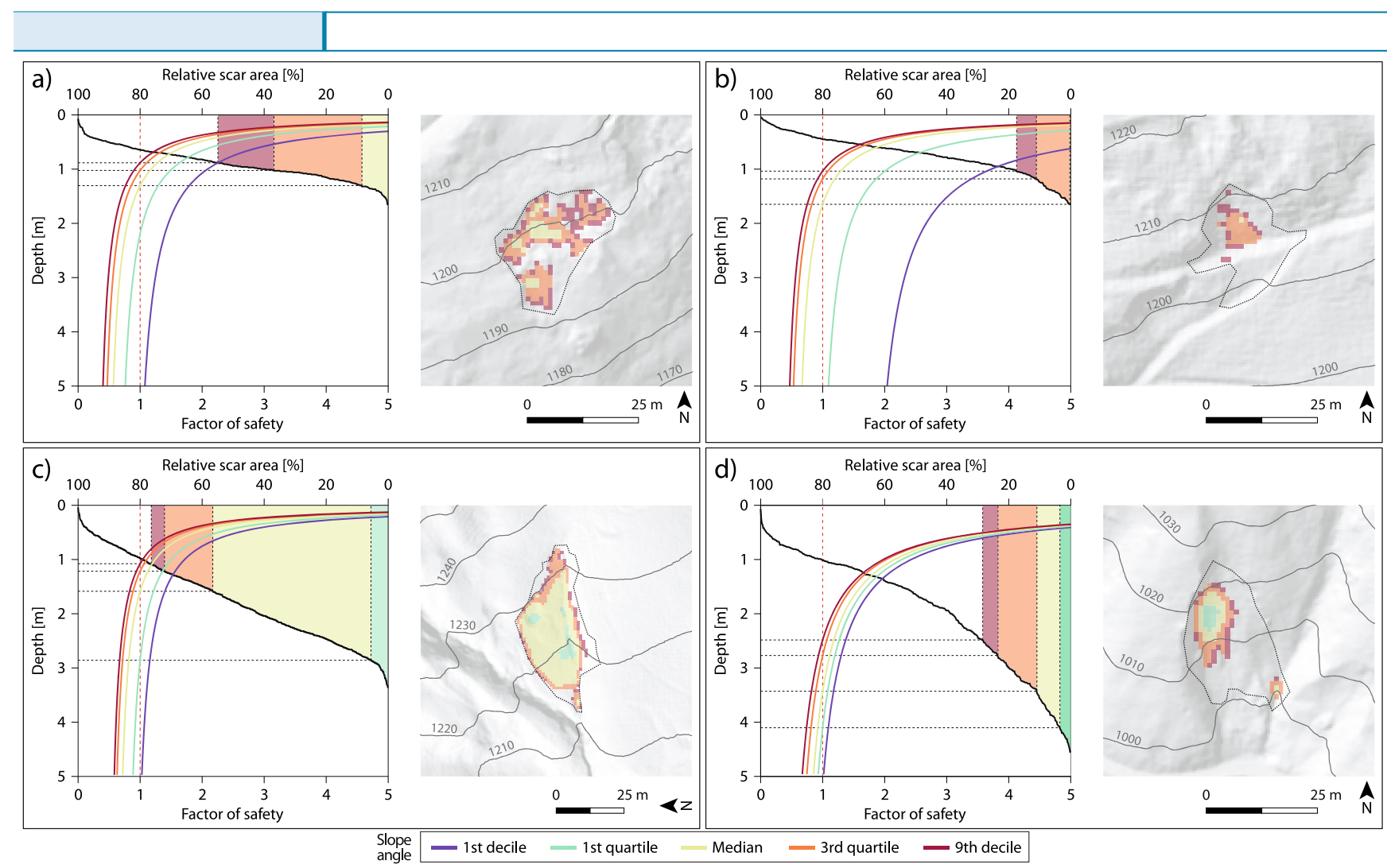

Fig. 14 FOS calculated for a range of landslide depths based on various slope angle values (Table 4) for the four landslide locations (a BIN, b BON, c MAZ, d ROH)
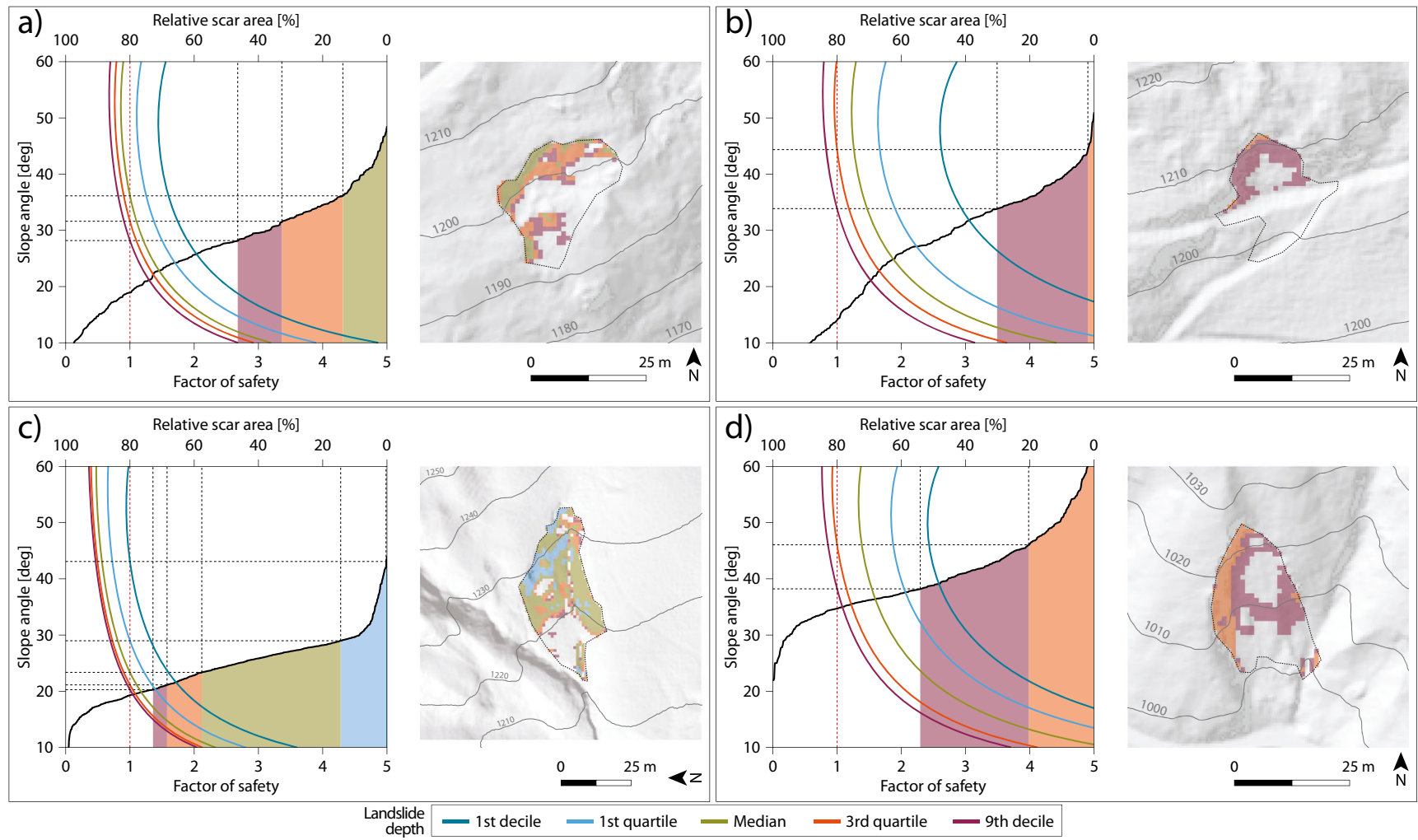

Fig. 15 FOS calculated for a range of slope angle values based on various landslide depths (Table 3) for the four landslide locations (a BIN, b BON, c MAZ, d ROH) 

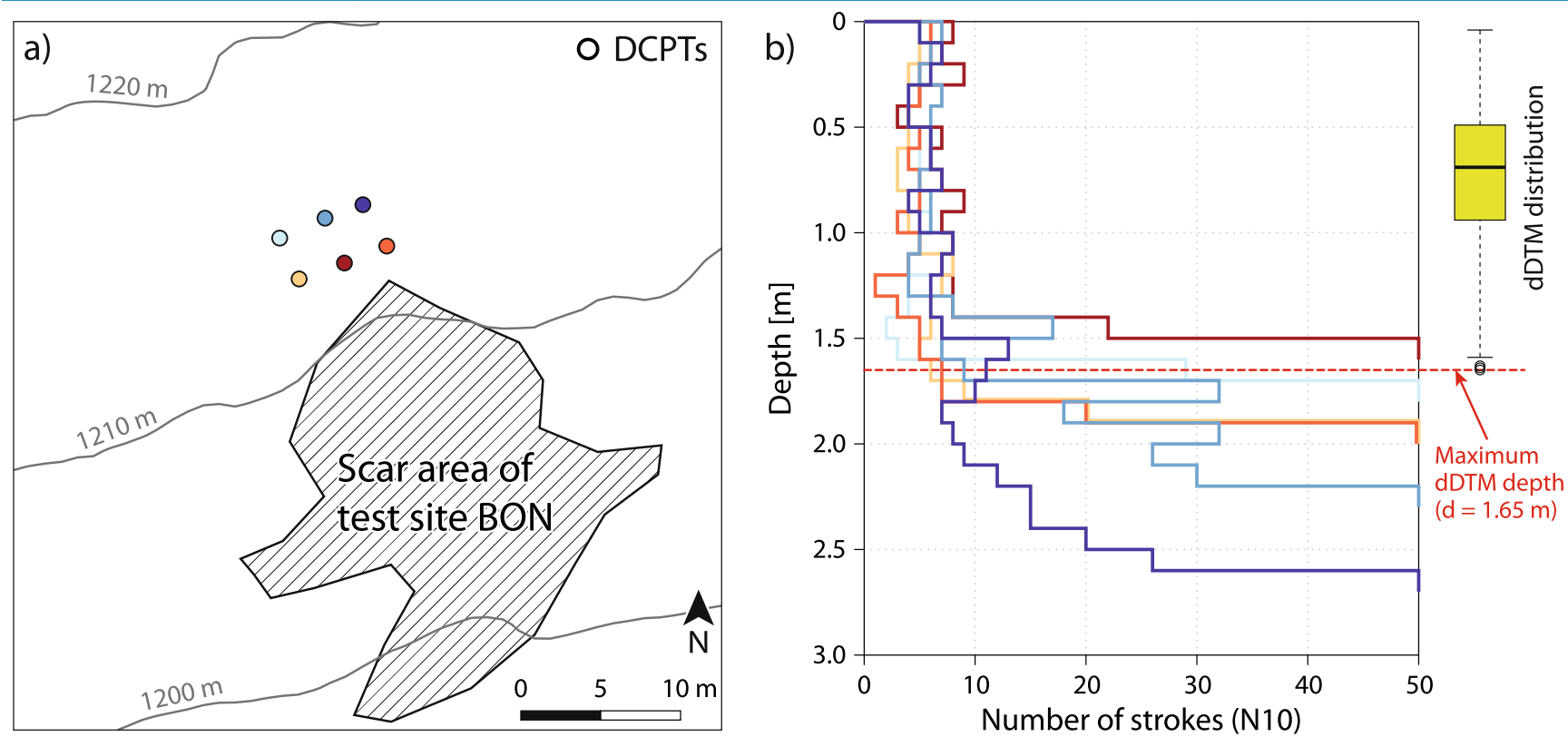

Fig. 16 Locations of the conducted DCPTs above landslide the scar area at test site BON (a) and the resulting penetration resistance plot (b). The colours of the points in (a) refer to the colour of the step plots in (b). The boxplot shows the landslide depth distribution derived from the dDTM within the scar area at the test site BON

within the scar areas. Material parameters were derived from laboratory tests conducted with material samples collected at the four test sites. The model results for the test sites using four approaches were compared. Landslide depths based on the dDTM were validated at one test site with the help of DCPTs.

It is possible to predict the four slope failures using the ISSM. For dry conditions, all test sites remain stable. Assuming fully saturated conditions and representativeness of the geotechnical parameters, the slope failures are predicted $($ FOS $<1)$ using the median slope angle derived from the post-event DTM and the maximum vertical landslide depth derived from a dDTM. Using Janbu's model including a $2 \mathrm{D}$ representation of landslide geometry, two out of four failures were predicted for fully saturated conditions. No slope failures were predicted using $3 \mathrm{D}$ models. The differing results may be explained by the influence of cohesion.

It is shown that with increasing depth, the influence of cohesion on the FOS decreases non-linearly. Therefore, a more detailed representation of landslide geometry including shallower areas may lead to a higher FOS due to the influence of cohesion. There, the increased stabilizing effect of cohesion enhances the overall FOS. This may explain the higher FOS resulting from the $2 \mathrm{D}$ approach (where the shallower parts along the down-slope profile are considered) and the even higher FOS resulting from the $3 \mathrm{D}$ approaches (where also the shallower lateral portions of the landslides are considered). The resulting FOS based on the ISSM using the median landslide depth better corresponds to the results of the $2 \mathrm{D}$ and $3 \mathrm{D}$ approaches.

Field measurements theoretically yield the maximum regolith depth. If the bedrock acts as the sliding surface, the maximum regolith depth corresponds to the maximum landslide depth. Using such measurements as input data for the ISSM, conservative predictions of slope stability are obtained. The assessment of slope stability involving the ISSM at catchment scale should therefore be considered a regional overview showing potential areas for more detailed investigations. This is particularly important if landslide volumes are of interest, which are generally overestimated by the ISSM when using the maximum regolith depth.

The failure of the $3 \mathrm{D}$ models to correctly predict the observed slope failures may be related to the variability of the geotechnical parameters. Sliding surfaces most likely coincide spatially with geotechnically susceptible areas, layers or interfaces, spaced in a more or less irregular way. Even though much effort was put in sampling and testing, it appears hardly feasible to parameterize such patterns of localized patches of low soil strength, increased water input or increased hydraulic conductivity, or the effects of the vegetation (de Lima Neves Seefelder et al. 2016). This means that either even more detailed studies including comprehensive material sampling and testing as well as regolith depth measurements, or appropriate techniques for a stochastic representation of the variability of the key parameters, are necessary for studies of single landslides or slopes.

\section{Acknowledgements}

Open access funding provided by University of Innsbruck and Medical University of Innsbruck. We thank the federal state of Vorarlberg for kindly providing data for this study. This work has been conducted within the project $\mathrm{C}_{3} \mathrm{~S}$-ISLS, which is funded by the Austrian Climate and Energy Fund, 5th ACRP Programme.

Open Access This article is distributed under the terms of the Creative Commons Attribution 4.0 International License (http:// creativecommons.org/licenses/by/4.o/), which permits unrestricted use, distribution, and reproduction in any medium, provided you give appropriate credit to the original author(s) and the source, provide a link to the Creative Commons license, and indicate if changes were made. 


\section{References}

Andrecs P, Markart G, Lang E, Hagen K, Kohl B, Bauer W (2002) Untersuchung der Rutschungsprozesse vom Mai 1999 im Laternsertal (Vorarlberg). BFW Berichte 127:55-87

Baum RL, Coe JA, Godt JW, Harp EL, Reid ME, Savage WZ, Schulz WH, Brien DL, Chleborad AF, McKenna JP, Michael JA (2005) Regional landslide-hazard assessment for Seattle, Washington, USA. Landslides 2(4):266-279. doi:10.1007/s10346-0050023-y

Baum RL, Savage WZ, Godt JW (2008) TRIGRS-A Fortran Program for Transient Rainfall Infiltration and Grid-Based Regional Slope-Stability Analysis, Version 2.0: Open-File Report 2008-1159. Tech. rep., U. S. Geological Survey

Bishop AW (1955) The use of the slip circle in the stability analysis of slopes. Géotechnique 5(1):7-17. doi:10.1680/geot.1955.5.1.7

Catani F, Segoni S, Falorni G (2010) An empirical geomorphology-based approach to the spatial prediction of soil thickness at catchment scale. Water Resour Res 46:W05508. doi:10.1029/2008WR007450

Cruden DM, Varnes DJ (1996) Landslide types and processes. In: Turner A, Schuster R (eds) Landslides: investigation and mitigation, Transportation Research Board Special Report 247. US National Research Council, Washington, DC, pp 36-75

Davis JL, Annan AP (1989) Ground-penetrating radar for high-resolution mapping of soil and rock stratigraphy. Geophys Prospect 37(5):531-551. doi:10.1111/j.13652478.1989.tb02221.x

Dietrich WE, Reiss R, Hsu ML, Montgomery DR (1995) A process-based model for colluvial soil depth and shallow landsliding using digital elevation data. Hydrol Process 9(34):383-400. doi:10.1002/hyp.3360090311

Fellenius W (1927) Erdstatische Berechnungen mit Reibung und Kohäsion (Adhäsion) und unter Annahme kreiszylindrischer Gleitflächen. W. Ernst \& Sohn, Berlin

Fellin W (2014) The rediscovery of infinite slope model / Die Wiederentdeckung der unendlich langen Böschung. Geomechanics and Tunnelling 7(4):299-305. doi:10.1002/geot.201400019

Friebe J (2007) Vorarlberg. Geologie der Österreichischen Bundesländer. Verlag der Geologischen Bundesanstalt (GBA), Wien

GGU (2016) Software applications for geotechnical calculations. Accessed 31 October 2016. URL http://www.ggu-software.com

Ghiassian H, Ghareh S (2008) Stability of sandy slopes under seepage conditions. Landslides 5(4):397-406. doi:10.1007/s10346-008-0132-5

Gioia E, Speranza G, Ferretti M, Godt JW, Baum RL, Marincioni F (2016) Application of a process-based shallow landslide hazard model over a broad area in Central Italy. Landslides 13(5):1197-1214. doi:10.1007/s10346-015-0670-6

Heissel W, Oberhauser R, Schmidegg 0 (1967) Geologische Karte des Walgaues, Vorarlberg 1:25.000. Verlag der Geologischen Bundesanstalt (GBA), Wien

Horn B (1981) Hill shading and the reflectance map. Proceedings of the IEEE 69(1):1447, DOI 10.1109/PROC.1981.11918

Hovland H (1977) Three-dimensional slope stability analysis method. J Geotech Eng Div 103(9):971-986

Hungr 0 (1987) An extension of Bishop's simplified method of slope stability analysis to three dimensions. Géotechnique 37(1):113-117. doi:10.1680/geot.1987.37.1.113

Hungr 0, Leroueil S, Picarelli L (2014) The Varnes classification of landslide types, an update. Landslides 11(2):167-194. doi:10.1007/s10346-013-0436-y

Janbu N (1954) Stability analysis of slopes with dimensionless parameters. Harvard soil mechanics series 46. PhD thesis. Harvard University, Cambridge

Lam L, Fredlund D (1993) A general limit equilibrium model for three-dimensional slope stability analysis. Can Geotech J 30(6):905-919. doi:10.1139/t93-089

de Lima Neves Seefelder C, Koide S, Mergili M (2016) Does parameterization influence the performance of slope stability model results? A case study in Rio de Janeiro, Brazil. Landslides:1-13. doi:10.1007/s10346-016-0783-6

Markart G, Perzl F, Kohl B, Luzian R, Kleemayr K, Ess B, Mayerl J (2007) Schadereignisse 22./23. August 2005 - Ereignisdokumentation und -analyse in ausgewählten Gemeinden Vorarlbergs. In: BFW-Dokumentation, vol 5, Bundesforschungs-und Ausbildungszentrum für Wald, Naturgefahren und Landschaft, Wien

Mergili M, Marchesini I, Rossi M, Guzzetti F, Fellin W (2014) Spatially distributed threedimensional slope stability modelling in a raster GIS. Geomorphology 206:178-195. doi:10.1016/j.geomorph.2013.10.008

Montrasio L, Valentino R, Losi GL (2011) Towards a real-time susceptibility assessment of rainfall-induced shallow landslides on a regional scale. Nat Hazards Earth Syst Sci 11(7):1927-1947. doi:10.5194/nhess-11-1927-2011

Morgenstern N, Price VE (1965) The analysis of the stability of general slip surfaces. Geotechnique 15(1):79-93. doi:10.1680/geot.1965.15.1.79
Oberhauser R (1982) Geologische Karte St. Gallen Süd und Dornbirn Süd 1:25.000. Verlag der Geologischen Bundesanstalt (GBA), Wien

Oberhauser R (1998) Erläuterungen zur geologisch-tektonischen Übersichtskarte von Vorarlberg 1: 200.000. Verlag der Geologischen Bundesanstalt (GBA), Wien

ÖNORM EN ISO 22476-2:2012 (2012) Geotechnische Erkundung und Untersuchung Felduntersuchungen - Teil 2: Rammsondierungen. Austrian Standards

Perumpral J (1987) Cone penetrometer applications - a review. Transactions of the ASAE 30(4):939-944. doi:10.13031/2013.30503

R Core Team (2016) R: A Language and Environment for Statistical Computing. Accessed 19 December 2016. URL https://www.R-project.org/

Sass 0 (2007) Bedrock detection and talus thickness assessment in the European Alps using geophysical methods. J Appl Geophys 62(3):254-269. doi:10.1016/ j.jappge0.2006.12.003

Skempton A, Hutchinson J (1969) Stability of natural slopes and embankment foundations. In: State of the art report, Seventh International Conference on Soil Mechanics and Foundation Engineering, Mexico, pp 291-340

Werner R, Auer I (2001a) Klima von Vorarlberg: Eine anwendungsorientierte Klimatographie. 1. Lufttemperatur, Bodentemperatur, Wassertemperatur, Luftfeuchte, Bewölkung, Nebel. Umweltinstitut des Landes Vorarlberg, Bregenz

Werner R, Auer I (2001b) Klima von Vorarlberg: Eine anwendungsorientierte Klimatographie. 2. Niederschlag und Gewitter, Schnee und Gletscher, Verdunstung, Luftdruck, Wind. Umweltinstitut des Landes Vorarlberg, Bregenz

Wiegand C, Kringer K, Geitner C, Rutzinger M (2013) Regolith structure analysis-a contribution to understanding the local occurrence of shallow landslides (Austrian Tyrol). Geomorphology 183:5-13. doi:10.1016/j.geomorph.2012.06.027

Xie M, Esaki T, Zhou G, Mitani Y (2003) Three-dimensional stability evaluation of landslides and a sliding process simulation using a new geographic information systems component. Environ Geol 43(5):503-512. doi:10.1007/s00254-002-0655-3

Xie M, Esaki T, Cai M (2004a) A GIS-based method for locating the critical 3D slip surface in a slope. Comput Geotech 31(4):267-277. doi:10.1016/j.compge0.2004.03.003

Xie M, Esaki T, Zhou G (2004b) GIS-based probabilistic mapping of landslide hazard using a three-dimensional deterministic model. Nat Hazards 33(2):265-282. doi:10.1023/ B:NHAZ.0000037036.01850.0d

Xie M, Esaki T, Qiu C, Wang C (2006) Geographical information system-based computational implementation and application of spatial three-dimensional slope stability analysis. Comput Geotech 33(4/5):260-274. doi:10.1016/j.compge0.2006.07.003

Zieher T, Perzl F, Rössel M, Rutzinger M, MeißI G, Markart G, Geitner C (2016) A multiannual landslide inventory for the assessment of shallow landslide susceptibility-two test cases in Vorarlberg, Austria. Geomorphology 259:40-54. doi:10.1016/j.geomorph.2016.02.008

\section{T. Zieher (- $)$}

Institute for Interdisciplinary Mountain Research,

Austrian Academy of Sciences,

Technikerstraße 21a, 6020, Innsbruck, Austria

e-mail: thomas.zieher@oeaw.ac.at

\section{T. Zieher}

Institute of Geography, University of Innsbruck,

Innrain 52f, 6020, Innsbruck, Austria

\section{B. Schneider-Muntau}

Unit of Geotechnical and Tunnel Engineering, Institute of Infrastructure,

University of Innsbruck,

Technikerstraße 13, 6020, Innsbruck, Austria

\section{Mergili}

Institute of Applied Geology,

BOKU University of Natural Resources and Life Sciences Vienna,

Peter-Jordan-Straße 82, 1190, Vienna, Austria

M. Mergili

Geomorphological Systems and Risk Research, Department of Geography and Regional Research,

University of Vienna,

Universitätsstraße 7, 1190, Vienna, Austria 